\title{
Investigation of macrocyclisation routes to 1,4,7-triazacyclononanes: efficient syntheses from 1,2-ditosylamides $\uparrow$
}

\author{
Graham Stones, Régis Tripoli, Colin L. McDavid, Kewin Roux-Duplâtre, Alan R. Kennedy, \\ David C. Sherrington and Colin L. Gibson*\$
}

Received 1st November 2007, Accepted 20th November 2007

First published as an Advance Article on the web 11th December 2007

DOI: $10.1039 / \mathrm{b} 716938 \mathrm{~h}$

Two routes to the synthesis of a cyclohexyl-fused 1,4,7-triazacyclononane involving macrocyclisations of tosamides have been investigated. In the first approach, using a classic Richman-Atkins-type cyclisation of a cyclohexyl-substituted 1,4,7-tritosamide with ethylene glycol ditosylate, afforded the cyclohexyl-fused 1,4,7-triazacyclononane in 5.86\% overall yield in four steps. The second, more concise, approach involving the macrocyclisation of trans-cyclohexane-1,2-ditosamide with the tritosyl derivative of diethanolamine initially gave poor yields $(<25 \%)$. The well-documented problems with efficiencies in macrocyclisations using 1,2-ditosamides led to the use of a wider range of 1,2-ditosamides including ethane-1,2-ditosamide and propane-1,2-ditosamide. These extended studies led to the development of an efficient macrocyclisation protocol using lithium hydride. This new method afforded 1,4,7-tritosyl-1,4,7-triazacyclononanes in good yield (57-90\%) from 1,2-ditosamides in a single step. These efficient methods were then applied to the preparation of a chiral cyclohexyl-fused 1,4,7-tritosyl-1,4,7-triazacyclononane (65-70\%). This key chiral intermediate was then converted into a copper(II) complex following detosylation and $N$-methylation. The resulting chiral copper(II) complex catalysed the aziridination of styrene but it did so in a racemic fashion.

\section{Introduction}

Polyazamacrocycles continue to stimulate considerable interest because of their varied coordination chemistry coupled with their biological properties and the synthetic utility of the derived metal ion complexes. ${ }^{1}$ More specifically, the tridentate 1,4,7triazacyclononanes are of particular interest because of their ability to stabilise both high and low oxidation states of various metal ions. ${ }^{2}$ In this context, transition metal complexes of 1,4,7triazacyclononane derivatives have been studied as biomimetics of manganese catalase, ${ }^{3,4}$ Photosystem $\mathrm{II}^{3,5}$ and hemocyanin. ${ }^{6}$ These biological model systems studies led to the development of manganese complexes of 1,4,7-triazacyclononane derivatives as potent alkene epoxidation catalysts. ${ }^{7}$ Indeed, stereoselective alkene epoxidation protocols have been developed while enantioselective epoxidations using manganese complexes of chiral 1,4,7triazacyclononane derivatives have been described by Beller et al., ${ }^{8}$ Bolm et al. ${ }^{9,10}$ and ourselves. ${ }^{11}$ Manganese complexes of derivatives of 1,4,7-triazacyclononane have also been used in the oxidation of sulfides, alcohols and alkanes. ${ }^{7}$ Recently, an iron(III) complex of 1,4,7-trimethyl-1,4,7-triazacyclononane was found to catalyse the atom transfer radical polymerisation of styrene. ${ }^{12}$ In addition, hydrolytic catalysts have been developed from copper(II), zinc(II) and iron(III) complexes of derivatives of 1,4,7-triazacyclononane which have been used in the cleavage of RNA, ${ }^{13} \mathrm{DNA}^{14,15}$ and

Department of Pure \& Applied Chemistry, University of Strathclyde, 295 Cathedral Street, Glasgow, UK G1 1XL.E-mail: c.l.gibson@strath.ac.uk $\dagger$ Electronic supplementary information (ESI) available: Instrumentation, general synthetic methods and full experimental procedures for the synthesis via Route B, including compounds; $( \pm)-\mathbf{3},( \pm)-\mathbf{6}( \pm)-\mathbf{1 0}, \mathbf{1 2}$, $( \pm)$-13. See DOI: $10.1039 / \mathrm{b} 716938 \mathrm{~h}$

$\$$ Based on G. Stones, Ph.D. Thesis, University of Strathclyde, 2003. peptides. ${ }^{16}$ Intriguingly, the copper(II) trifluoroacetate complex of 1,4,7-triisopropyl-1,4,7-triazacyclononane was reported by Halfen et al. to be a remarkably efficient catalyst for the achiral aziridination of alkenes. ${ }^{17}$

Given the foregoing interest in 1,4,7-triazacyclononanes it is not surprising that chiral analogues have been prepared, including those with one, ${ }^{11 b, 18}$ two $\left[(\mathrm{C}-2,3),{ }^{19}(\mathrm{C}-2,5)^{20}\right.$ and $(\mathrm{C}$ $\left.2,6)^{11 a, 21,22}\right]$ and three ${ }^{10}$ stereocentres on the carbon backbone of the macrocyclic ring. Despite this significant synthetic interest, the use of complexes of metal ions and chiral 1,4,7-triazacyclononanes, generated in situ or isolated entities, have been limited to enantioselective epoxidations. ${ }^{8-11}$ However, a copper(II) complex of a chiral 4-oxa-1,7-diazonane has been used as a catalyst in the racemic hetero-Diels-Alder cycloaddition. ${ }^{19 c}$ Therefore, we were interested in trying to extend the catalytic repertoire of chiral 1,4,7-trizacyclononane-metal ion complexes in asymmetric transformations. We were particularly excited by the achiral alkene aziridination of Halfen et al. using copper(II) 1,4,7-triisopropyl1,4,7-triazacyclononane (vide supra) ${ }^{17}$ and wished to investigate chiral variants. Furthermore, we were keen to extend our investigations in asymmetric epoxidation studies using chiral manganese complexes. ${ }^{11,23}$ Since high enantiomeric excess had been claimed

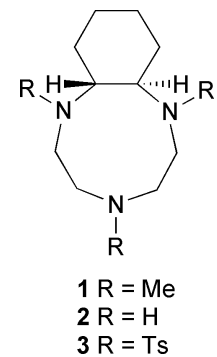


for alkene epoxidations using manganese complexes of cyclohexylfused azamacrocycle $\mathbf{1},{ }^{8}$ we wished to prepare and investigate complexes of this conformationally constrained system.

The cyclohexyl-fused azamacrocycle 1 was prepared by Beller et al. from the corresponding non-methylated derivative $\mathbf{2}$, which, in-turn, was accessed from the tritosamide $3 .{ }^{19 a}$ At the outset of our work, Beller et al. had reported the preparation of cyclohexylfused tritosamide 3 by the macrocyclisation of the disodium salt of cyclohexyl ditosamide $\mathbf{4}$ with tosyl ester $\mathbf{5}$ in $68 \%$ yield (Scheme 1, Route A). ${ }^{19 a}$ In contrast, Lawrence and co-workers prepared the cyclohexyl-fused tritosamide 3 in only $28 \%$ yield using cyclohexyl ditosamide $\mathbf{4}$ with ditosyl ester $\mathbf{5}$ in DMF with potassium carbonate. ${ }^{19 b}$ After completion of our synthetic studies, Watkinson and co-workers also reported modest yields in the macrocyclisation of cyclohexyl ditosamide $\mathbf{4}$ and tosyl ester $\mathbf{5} .{ }^{19 d}$ This latter group attributed the moderate macrocyclisation yield to geometric constraints as a result of ring strain. However, it had been previously documented that macrocyclisations of 1,2ditosamides to provide tritosylamides of 1,4,7-triazacyclononanes do so in only modest yield. ${ }^{18 c, 24}$ Searle and Geue concluded that these low yields were a consequence of inhibition of the first substitution step, that is the reaction of a bis-anion of a 1,2-ditosamide with ditosyl ester 5. It was postulated that this inhibition may have been due to steric and/or electronic effects in the 1,2-ditosamide bis-anion. ${ }^{24}$ Searle and Geue were, however, able to carry out successful macrocyclisations provided that 1,2-ditosamides were not used as the source of the nucleophilic component. Instead, an alternative disconnection involving classical Richman-Atkins cyclisations with ethylene glycol ditosylate and the tritosamide from diethylenetriamine provided good cyclisation yields.
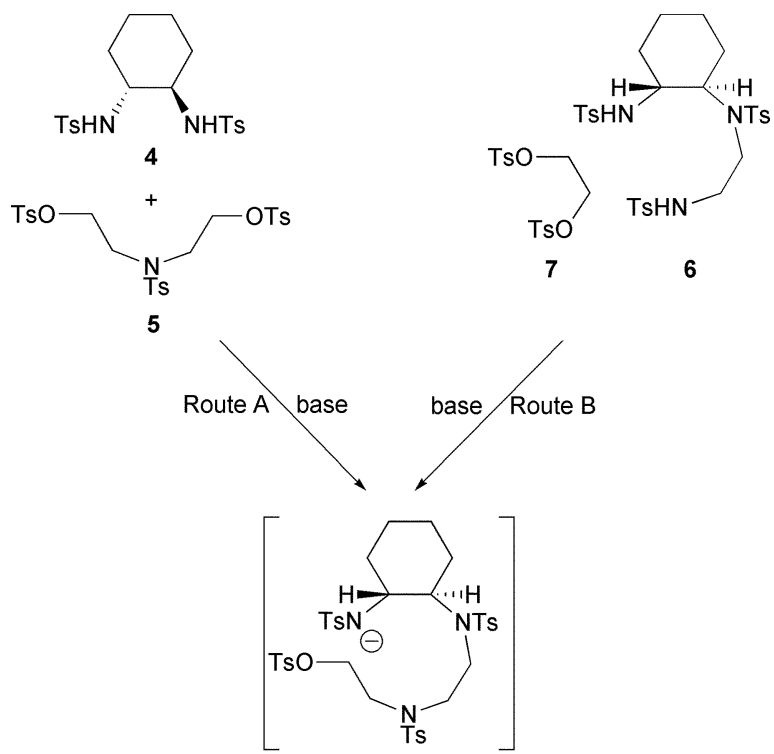

8

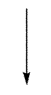

3

Scheme 1

The focus for this study was to investigate alternative cyclisation routes to the cyclohexyl-fused tritosamide 3 (Scheme 1). After developing efficient routes to tritosamide $\mathbf{3}$ we then planned to prepare the $N$-methyl derivative $\mathbf{1}$ and then prepare manganese and copper(II) complexes. These complexes were to be studied in catalytic asymmetric alkene epoxidations and aziridinations.

In order to develop efficient routes to the tritosamide $\mathbf{3}$ it was important to address the issues of the cyclisation chemistry. In view of the observations of Searle and Geue (vide supra) we envisiged an alternative disconnection of tritosamide 3 (Scheme 1, Route B). This route involved the classic Richman-Atkins cyclisation of the 1,4,7-tritosamide 6 with ethylene glycol ditosylate 7. Since both Route A and Route B proceed via common intermediate $\mathbf{8}$, then these studies may lead to an understanding of the moderate yields obtained in Route A (Scheme 1).

\section{Results and discussion}

Our alternative approach to the synthesis of cyclohexyl-fused tritosamide 3, via route B (Scheme 1), started from the racemic cyclohexyl diamine $( \pm)-9$ which was monotosylated using 0.31 equivalents of tosyl chloride which gave the amino tosyl amide $( \pm)-\mathbf{1 0}$ [ $83 \%$ based on limiting tosyl chloride, $27 \%$ based on $( \pm)-9$ ] (Scheme 2). ${ }^{25}$ A two-step conversion of ethanolamine 11 into tosyl aziridine 12 ( $70 \%$ over two steps) was carried out using a modification of the method of Bulkowski and co-workers. ${ }^{26}$ Bulkowski and co-workers had reported the effective ring opening of aziridine 12 with 1,2-amino tosamides. ${ }^{26}$ Analogous ring opening of the aziridine $\mathbf{1 2}$ with amino tosyl amide $( \pm)-\mathbf{1 0}$ in toluene at reflux afforded the ditosamide amine $( \pm)-\mathbf{1 3}(45 \%)$. This ring opening was sluggish $(60 \mathrm{~h})$ and may reflect the hindered nature of the amino functionality in amino tosyl amide $( \pm)-10 . N$-Tosylation of ditosamide amine $( \pm)-\mathbf{1 3}$ with tosyl chloride in pyridine smoothly afforded the tritosamide $( \pm)-6(72 \%)$. Ritchman-Atkins
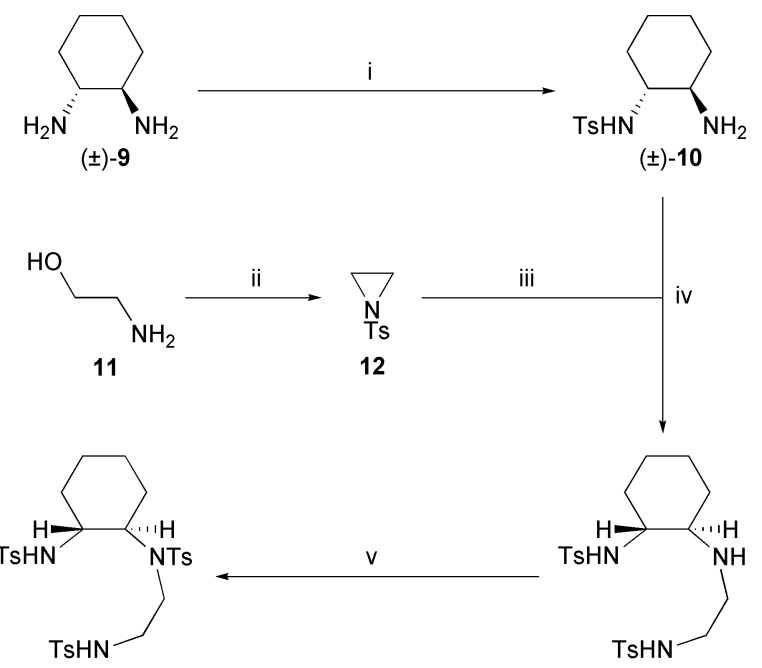

$( \pm)-6$
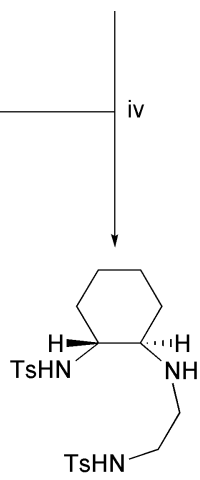

$( \pm)-13$

$( \pm)-3$

Scheme 2 Reagents and conditions: i, 0.31 equiv. $\mathrm{TsCl}, \mathrm{CH}_{2} \mathrm{Cl}_{2}, 3 \mathrm{~N}$ $\mathrm{NaOH}, 0{ }^{\circ} \mathrm{C}, 83 \%$ [27\% based on ( \pm )-9]; ii, 2 equiv. TsCl, Py, $73 \%$; iii, $\mathrm{NaH}$, THF, $96 \%$; iv, toluene, $\Delta, 45 \%$; v, TsCl, $\mathrm{Py}, 72 \%$; vi, (a) $\mathrm{NaH}$, DMF, $25{ }^{\circ} \mathrm{C}$, (b) $\left(\mathrm{CH}_{2} \mathrm{OTs}\right)_{2}, 80{ }^{\circ} \mathrm{C}, 67 \%$. 
macrocyclisation by treatment of tritosamide $( \pm)-6$ with two equivalents of sodium hydride together with ethylene glycol ditosylate readily gave the target macrocycle tritosamide $( \pm)-3(67 \%)$.

The yield obtained in the macrocyclisation of tritosamide $( \pm)-6(67 \%)$ (Scheme 1, Route B) is very much in line with the yields of other Richman-Atkins cyclisations (53-83\%) using tritosamides and ethylene glycol ditosylate to give 1,4,7triazacyclonane derivatives. ${ }^{11,18 e, 21,22,24,27}$ This observation does not appear to support the conclusions of Watkinson et al. that the poor yields in the macrocyclisation of ditosamide $\mathbf{4}$ with ditosyl ester $\mathbf{5}$ to give macrocycle $\mathbf{3}$ (Scheme 1, Route A) are a consequence of geometric constraints from ring strain. Both Routes A and B (Scheme 1) proced via the common intermediate $\mathbf{8}$, and our results, therefore, indicate that cyclisation of anion $\mathbf{8}$ is not particularly hindered. However, the sluggish reaction between aziridine $\mathbf{1 2}$ with amino tosyl amide $( \pm)$-10 may suggest that the first substitution step of the dianion of ditosamide $\mathbf{4}$ by ditosyl ester $\mathbf{5}$ is hindered.

Although Richman-Atkins macrocyclisation of cyclohexyl tritosamide $( \pm)-6$ efficiently gave the cyclohexyl-fused macrocycle tritosamide $( \pm)-\mathbf{3}$, the overall yield was unacceptably low $(5.86 \%)$ over four steps. This is a consequence of the low yield in two steps: firstly, in the monotosylation of diamine $( \pm)-9[83 \%$ based on limiting tosyl chloride, $27 \%$ based on ( \pm )-9]; and secondly, in the ring opening of aziridine $\mathbf{1 2}$ with amino tosyl amide $( \pm$ )-10 (45\%) (Scheme 2). Consequently, we decided to re-investigate the reactions of 1,2-ditosamides with tosyl ester 5 (Scheme 1, Route A). Thus, the 1,2-diamines $( \pm)-\mathbf{9}$ and 15a-c were converted into the corresponding 1,2-ditosamides ( \pm )-4 and 16a-c (68-79\%) using tosyl chloride and base $\left(\mathrm{Et}_{3} \mathrm{~N}\right.$ or $\left.{ }^{i} \mathrm{PrNEt}_{2}\right)$ (Scheme 3). Additionally, the enantiopure $(R, R)-\mathbf{4}$ was prepared by resolution of 1,2-diamine ( \pm -9 $\mathbf{9}$ via the tartrate salt $\mathbf{1 4}(85 \%){ }^{28}$ Subsequent ditosylation of the salt $\mathbf{1 4}$, using a modification of the monotosylation conditions of Walsh and co-workers, ${ }^{29}$ afforded the enantiopure cyclohexyl ditosamide $(R, R)-\mathbf{4}(85 \%){ }^{19 b, c}$

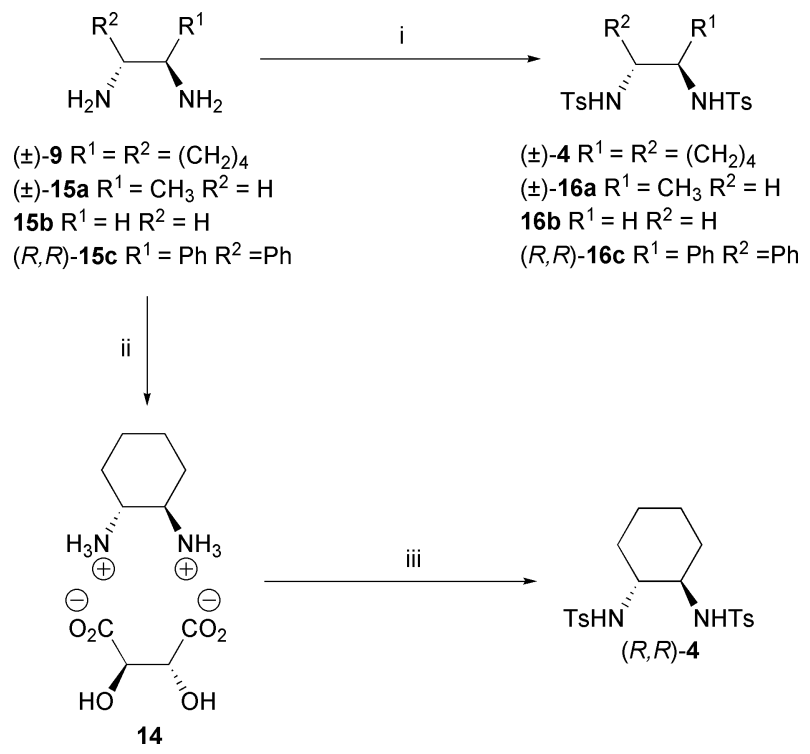

Scheme 3 Reagents and conditions: i, TsCl, $\mathrm{Et}_{3} \mathrm{~N}$ or ${ }^{i} \mathrm{PrNEt}_{2}, \mathrm{CH}_{2} \mathrm{Cl}_{2}$, 68-79\%; ii, (a) L-(+)-(2R,3R) tartaric acid, $70{ }^{\circ} \mathrm{C}$, (b) $\mathrm{AcOH}, 90{ }^{\circ} \mathrm{C}, 85 \%$; iii, TsCl, $1.2 \mathrm{~N} \mathrm{NaOH}, \mathrm{CH}_{2} \mathrm{Cl}_{2}, 85 \%$.
With access to the 1,2-ditosamides $\mathbf{4}$ and $\mathbf{1 6 a - c}$ in hand, we investigated the macrocyclisation with tosyl ester 5 (Scheme 4, Table 1). In the first instance, we repeated the macrocyclisation of cyclohexyl ditosamide ( \pm )-4 and tosyl ester $\mathbf{5}$ as previously reported by Golding et al. ${ }^{19 b}$ In this case, a yield of $18 \%$ was achieved for macrocycle $( \pm)-3$, in broad agreement with the yields observed by Golding et al. $(28 \%)^{19 b}$ and Watkinson and co-workers $(20 \%)^{19 c}$ (Table 1, entry 1, method A). In contrast, Beller et al. had used the sodium salt of cyclohexyl $(R, R)-\mathbf{4}$ with tosyl ester $\mathbf{5}$, which cyclised to provide cyclohexyl-fused macrocycle $(R, R)-3$ in $68 \% .{ }^{19 a}$ In our hands, this cyclisation gave cyclohexyl-fused $(R, R)-3$ in a disappointing $23 \%$, identical to that observed by Watkinson and co-workers $^{19 c}$ (Table 1, entry 2 , method B).

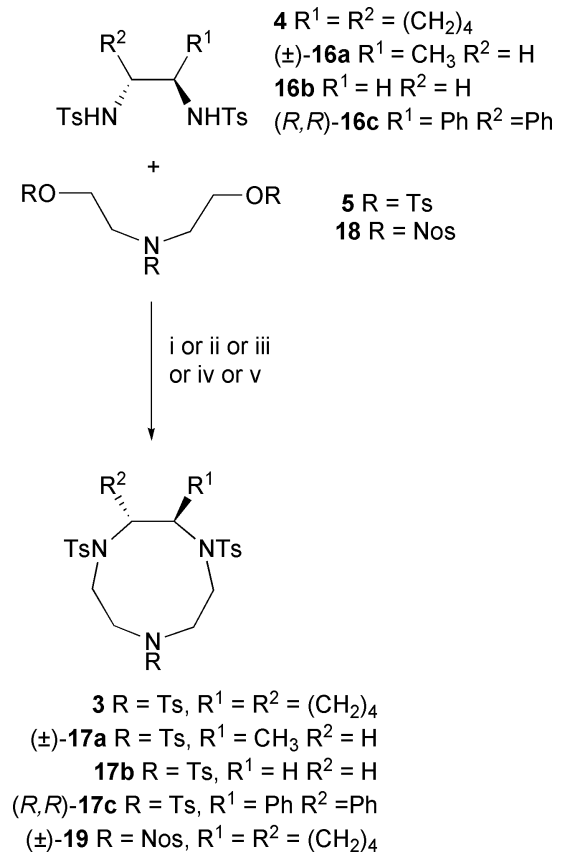

Scheme 4 Reagents and conditions: $\mathrm{i}$, (method A) $\mathrm{K}_{2} \mathrm{CO}_{3}, \mathrm{DMF}, 50{ }^{\circ} \mathrm{C}$, $7 \mathrm{~d}$; ii, (method B) (a) NaOEt, EtOH (b) 5, DMF, $100^{\circ} \mathrm{C}$; iii, (method C) (a) 2 equiv. $\mathrm{NaH}, \mathrm{DMF}$, (b) $5, \mathrm{DMF}, 70^{\circ} \mathrm{C}$; iv (method $\mathrm{D}$ ) disodium salt of $16 \mathbf{a}, 5$, DMSO, $100{ }^{\circ} \mathrm{C}$; v, (method E) (a) 2 equiv. $\mathrm{LiH}, \mathrm{DMF}, 70{ }^{\circ} \mathrm{C}$, (b) 5 or $18, \mathrm{DMF}, 50^{\circ} \mathrm{C}, 7 \mathrm{~d}$.

The low yields observed in the macrocyclisation of 1,2ditosamide $\mathbf{4}$ and ditosyl ester $\mathbf{5}$ taken together with the inefficient formation of cyclohexyl ditosamide amine ( \pm )-13 from amino tosyl amide ( \pm )-10 and aziridine $\mathbf{1 2}$ (Scheme 2 ) initially suggested that steric hindrance in both cyclohexyl 1,2-ditosamide $\mathbf{4}$ and amino tosyl amide $( \pm)$-10 may have been a problem. In order to understand these issues we chose to investigate the less sterically demanding propane-1,2-ditosamide $( \pm)$-16a as the source of the nucleophile in macrocyclisation. Given the previous success of the macrocyclisation conditions using two equivalents of sodium hydride in the formation of cyclohexyl-fused azamacrocycle $( \pm)-\mathbf{3}$ from 1,4,7-tritotosamide $( \pm$ )-13 (Scheme 1, Route B), we decided to use sodium hydride in DMF with propane-1,2-ditosamide $( \pm)-\mathbf{1 6 a}{ }^{24}$ Thus, cyclisation of propane-1,2-ditosamide $( \pm)$-16a under these conditions (conditions $\mathrm{C}$, Table 1) with ditosyl ester 5 gave the mono-substituted macrocycle $( \pm)-17 \mathbf{a}$ in a meagre $10 \%$ (entry 3, Table 1). This observation was in line with the results 
Table 1 Investigation of macrocyclisation methods using 1,2-ditosamides 4 and 16a-c with sulfonates 5 and $\mathbf{1 8}$ (Scheme 4)

\begin{tabular}{|c|c|c|c|c|c|}
\hline Entry & Ditosamide $\left(\mathrm{R}^{1}, \mathrm{R}^{2}\right)$ & Electrophile $(\mathrm{P})$ & Method $^{a}$ & Macrocyclic product $\left(\mathrm{R}^{1}, \mathrm{R}^{2}\right)$ & Yield (\%) (Lit. Yield (\%)) \\
\hline 1 & $( \pm)-\mathbf{4}\left(\mathrm{R}^{1}=\mathrm{R}^{2}=\left(\mathrm{CH}_{2}\right)_{4}\right)$ & $5\left(\mathrm{R}=\mathrm{SO}_{2} \mathrm{C}_{6} \mathrm{H}_{4} \mathrm{CH}_{3}\right)$ & A & $( \pm)-3\left(\mathrm{R}^{1}=\mathrm{R}^{2}=\left(\mathrm{CH}_{2}\right)_{4}\right)$ & $18\left(28,{ }^{19 b} 20^{19 c}\right)$ \\
\hline 2 & $( \pm)-$ or $(R, R)-4\left(\mathrm{R}^{1}=\mathrm{R}^{2}=\left(\mathrm{CH}_{2}\right)_{4}\right)$ & $5\left(\mathrm{R}=\mathrm{SO}_{2} \mathrm{C}_{6} \mathrm{H}_{4} \mathrm{CH}_{3}\right)$ & $\mathrm{B}$ & $( \pm)-$ or $(R, R)-3\left(\mathrm{R}^{1}=\mathrm{R}^{2}=\left(\mathrm{CH}_{2}\right)_{4}\right)$ & $23\left(68,{ }^{19 a} 23^{19 c}\right)$ \\
\hline 4 & $( \pm)-16 \mathbf{a}\left(\mathrm{R}^{1}=\mathrm{CH}_{3}, \mathrm{R}^{2}=\mathrm{H}\right)$ & $5\left(\mathrm{R}=\mathrm{SO}_{2} \mathrm{C}_{6} \mathrm{H}_{4} \mathrm{CH}_{3}\right)$ & $\mathrm{D}$ & $( \pm)-17 \mathbf{a}\left(\mathrm{R}^{1}=\mathrm{CH}_{3}, \mathrm{R}^{2}=\mathrm{H}\right)$ & $\left(20^{18 d}\right)$ \\
\hline 5 & $( \pm)-16 a\left(R^{1}=C_{3}, R^{2}=H\right)$ & $5\left(\mathrm{R}=\mathrm{SO}_{2} \mathrm{C}_{6} \mathrm{H}_{4} \mathrm{CH}_{3}\right)$ & $\mathrm{B}$ & $( \pm)-17 a\left(R^{1}=C_{3}, R^{2}=H\right)$ & $\left(60^{18 a}\right)$ \\
\hline 6 & $16 b\left(R^{1}=R^{2}=H\right)$ & $5\left(\mathrm{R}=\mathrm{SO}_{2} \mathrm{C}_{6} \mathrm{H}_{4} \mathrm{CH}_{3}\right)$ & $\mathrm{C}^{b}$ & $17 b\left(R^{1}=R^{2}=H\right)$ & $\left(25^{24}\right)^{\prime}$ \\
\hline 7 & $16 \mathbf{b}\left(\mathrm{R}^{1}=\mathrm{R}^{2}=\mathrm{H}\right)$ & $5\left(\mathrm{R}=\mathrm{SO}_{2} \mathrm{C}_{6} \mathrm{H}_{4} \mathrm{CH}_{3}\right)$ & $\mathrm{E}$ & $\mathbf{1 7} \mathbf{b}\left(\mathrm{R}^{1}=\mathrm{R}^{2}=\mathrm{H}\right)$ & 91 \\
\hline 10 & $(R, R)-\mathbf{4}\left(\mathrm{R}^{1}=\mathrm{R}^{2}=\left(\mathrm{CH}_{2}\right)_{4}\right)$ & $5\left(\mathrm{R}=\mathrm{SO}_{2} \mathrm{C}_{6} \mathrm{H}_{4} \mathrm{CH}_{3}\right)$ & $\mathrm{E}$ & $(R, R)-3\left(\mathrm{R}^{1}=\mathrm{R}^{2}=\left(\mathrm{CH}_{2}\right)_{4}\right)$ & $65-70$ \\
\hline 11 & $(R, R)-\mathbf{4}\left(\mathrm{R}^{1}=\mathrm{R}^{2}=\left(\mathrm{CH}_{2}\right)_{4}\right)$ & $18\left(\mathrm{R}=\mathrm{SO}_{2} \mathrm{C}_{6} \mathrm{H}_{4} \mathrm{NO}_{2}\right)$ & $\mathrm{E}$ & $( \pm)-19\left(\mathrm{R}^{1}=\mathrm{R}^{2}=\left(\mathrm{CH}_{2}\right)_{4}\right)$ & 57 \\
\hline
\end{tabular}

${ }^{a}$ Method A: $\mathrm{K}_{2} \mathrm{CO}_{3}$, DMF, $50{ }^{\circ} \mathrm{C}$; method B: (a) NaOEt, EtOH, (b) 5, DMF, $100{ }^{\circ} \mathrm{C}$; method C: (a) 2 equiv. NaH, DMF, (b) 5, DMF, $70{ }^{\circ} \mathrm{C}$; method D: disodium salt of $\mathbf{1 6 a}, \mathbf{5}$, DMSO, $100{ }^{\circ} \mathrm{C}$; method E: (a) 2 equiv. LiH, DMF, $70{ }^{\circ} \mathrm{C}$ (b) $\mathbf{5}$ or $\mathbf{1 8}$, DMF, $50{ }^{\circ} \mathrm{C}$. ${ }^{b}$ Cyclisation step carried out at $105{ }^{\circ} \mathrm{C}$.

of Graham and Weatherburn ${ }^{18 d}$ who cyclised the disodium salt of propane ditosamide( \pm -16a with ditosyl ester $\mathbf{5}$ in DMSO at $100{ }^{\circ} \mathrm{C}$ which gave the macrocycle $( \pm)-\mathbf{1 7 a}$ in $20 \%$ yield (entry 4 , Table 1, method D). This is in contrast to the findings of Mason and Peacock who claimed a $60 \%$ yield of macrocycle $(R)-\mathbf{1 7}$ a by reaction of the disodium salt of $(R)$-16a and ditosyl ester 16a using DMF at $100{ }^{\circ} \mathrm{C}$ (entry 5, Table 1$) .{ }^{18 a}$ However, even with the less sterically demanding ethane-1,2-ditosamide $\mathbf{1 6 b}$ Searle and Geue formed the parent 1,4,7-tritosyl-1,4,7-triazacyclononane $\mathbf{1 7 b}$ in only $25 \%$ using two equivalents of sodium hydride in DMF at $105^{\circ} \mathrm{C}$ (entry 6, Table 1). ${ }^{24}$ Indeed, it was Searle and Geue who first delineated the problems in the formation of 1,4,7-tritosyl-1,4,7triazacycloalkanes using dianions of 1,2-ditosamides. These workers postulated that steric and/or electronic effects inhibit the first nucleophilic substitution step in the reaction of 1,2-ditosamide dianions with bis-electrophiles ( $c f$. Route A, Scheme 1). The lack of a clear correlation of yield of macrocycle with the anticipated steric encumbrance of 1,2-ditosamides $\mathbf{4}$ and 16a in our results (entries 13 , Table 1) argues against just steric effects. However, electronic effects, solubility and nucleophilicity of 1,2-ditosamide dianions remained as possible causes for low yields in macrocyclisations.

In the context of the above issues of cyclisation of dianions of 1,2-ditosamides we wondered if alternatives to the sodium counterion might be helpful in developing efficient routes to cyclohexylfused macrocycle 3 via 1,2-ditosamides (Route A, Scheme 1). In this context, caesium carbonate has been found to be beneficial in Richman-Atkins cyclisations ${ }^{30}$ and in macrolactonisations. ${ }^{31}$ These observations were rationalised in terms of the basicity of caesium bicarbonate ${ }^{30}$ and in terms of ion-paring properties of caesium salts ${ }^{31}$ rather than a templating effect of the caesium cation. However, in related macrocyclisations of cyclohexyl ditosamide $\mathbf{4}$ using caesium carbonate we had observed poor yields of macrocycles. ${ }^{32}$ This suggested that ion-pairing properties of salts of cyclohexyl ditosamide $\mathbf{4}$ may not be the source of low macrocyclisation yields. We wondered, from our experimental observations, if solubility of dianions of 1,2-ditosamides might be an issue with low macrocyclisation yields.

Lithium salts are markedly different from the other alkali metal salts. ${ }^{33}$ Unlike the latter, the salts lithium chloride and lithium bromide are somewhat soluble in polar organic solvents such as alcohols and ethers. The solubility of these salts can be attributed to the relatively strong coordination of solvent molecules around the small lithium cation that has a large surface to charge density $\left(\mathrm{Li}^{+} 0.13 \mathrm{Z} \AA^{-3}\right){ }^{33}$ Therefore, we hoped that the use of lithium counterions in dianions of 1,2-ditosamides would provide for a more effective macrocyclisation. Unfortunately, lithium carbonate is not basic enough to deprotonate secondary tosamides ${ }^{30}$ but we anticipated that lithium hydride might result in effective macrocyclisations of 1,2-ditosamides. Accordingly, treatment of ethylene 1,2-ditosamide $\mathbf{1 6}$ with two equivalents of lithium hydride in DMF at $70{ }^{\circ} \mathrm{C}$ followed by addition of ditosyl ester 5 at $50{ }^{\circ} \mathrm{C}$ gave the parent 1,4,7-tritosyl-1,4,7triazacyclononane $\mathbf{1 7 b}$ in an unprecedented $91 \%$ yield (entry 7 , Table 1). To explore the scope of this process we investigated the use of propyl 1,2-ditosamide ( \pm )-16a and diphenyl 1,2-ditosamide $(R, R)$-16c (entries 8 and 9, Table 1). The former provided the methyl-substituted macrocycle $17 \mathbf{a}$ in $60 \%$ yield while the latter failed to afford the diphenyl macrocycle 17c. Clearly, there is a complex interplay of steric and counterion effects at work in these macrocyclisations. The use of lithium as the cation enables some of these cyclisations to proceed efficiently. However, the decrease in yield on increasing the steric requirements of the 1,2-ditosamide (entries 7 and 8, Table 1) indicates that the macrocyclisation is subject to some steric hindrance factors. With these observations in mind we then investigated the key macrocyclisation of cyclohexyl ditosamide $(R, R)-\mathbf{4}$ with ditosyl ester $\mathbf{5}$. Satisfyingly, the cyclohexyl macrocycle $(R, R)-3$ was obtained in consistently good yields $(65-70 \%)$ (entry 10, Table 1). $\S$ Since 4-nitrosulfonamides (nosyl; Nos) have been used in heterocyclic cyclisations ${ }^{34}$ and the nosyl group can be removed under mild conditions we investigated our cyclisation protocol with cyclohexyl ditosamide $( \pm)-\mathbf{4}$ and bisnosyl ester 18. This macrocyclisation gave the ditosamide nosyl amide 19 in $57 \%$ yield (entry 11 , Table 1 ).

The efficient macrocyclisation of $\mathbf{4}$ with $\mathbf{5}$ (Scheme 4) suggests, in contrast to the observations of Watkinson and co-workers, ${ }^{19 c, d}$ that the cyclohexyl macrocycle $\mathbf{3}$ is not subject to undue ring strain to prevent macrocyclisation. Indeed, this approach presents a much more effective synthesis of $\mathbf{3}$ (two steps from salt 14, 55\% overall) in contrast to Route A (Scheme 1) (four steps, $5.86 \%$ overall)

Having established an effective route to the chiral macrocycle $(R, R)-\mathbf{3}$ (Schemes 3 and 4 ) we wished to prepare metal complexes

$\S$ Three separate workers in these laboratories have achieved consistent yields in the synthesis of $(R, R)-3$. 
of the corresponding $N$-alkyl derivatives. Thus, deprotection of the chiral macrocyclic tritosylamide $(R, R)-\mathbf{3}$ was accomplished via using lithium in ammonia, ${ }^{18 e}$ which afforded the hydrochloride salt $(R, R)-20(73 \%)$ (Scheme 5). The macrocyclic amine hydrochloride $(R, R)-20$ was converted into its free base $(R, R)-\mathbf{2}$ with aqueous $\mathrm{NaOH}$. Methylation of the free base $(R, R)-2$ was conveniently achieved using the Eschweiler-Clarke $N$-methylation procedure which afforded the $N$-methyl macrocycle $(R, R)-1(79 \%){ }^{35}$

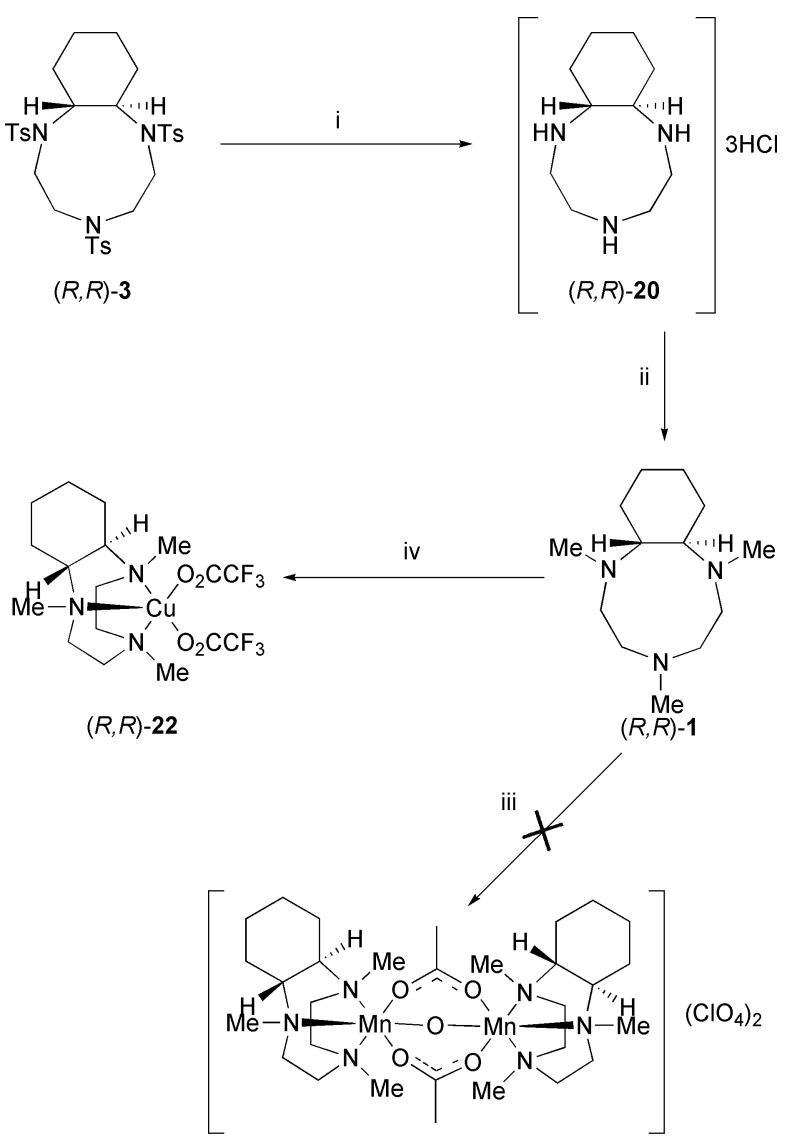

21

Scheme 5 Reagents and conditions: i, (a) $\mathrm{Li}, \mathrm{NH}_{3}, \mathrm{EtOH}$, (b) aq. $\mathrm{HCl}$ (73\%); ii, (a) aq. $\mathrm{NaOH}$, (b) $\mathrm{HCO}_{2} \mathrm{H}, \mathrm{HCHO}, \Delta, 24 \mathrm{~h}(79 \%)$; iii, $\mathrm{Mn}(\mathrm{OAc})_{3}$, $\mathrm{MeOH}-\mathrm{H}_{2} \mathrm{O}(9: 1), \mathrm{NaClO}_{4}$; iv, (a) $\mathrm{CuCl}_{2}, \mathrm{CH}_{3} \mathrm{CN}$ (b) $\mathrm{AgO}_{2} \mathrm{CCF}_{3}$.

With adequate quantities of chiral macrocycle $(R, R)-\mathbf{1}$ in hand, we wished to prepare the ( $\mu$-oxo)-bis( $\mu$-acetoxy) perchlorate salt 21 and derivatives. The corresponding hexafluorophosphate salt of 21 had been prepared by Beller et al., ${ }^{19 a}$ albeit in $18 \%$ yield. Beller et al. used the hexafluorophosphate salt of $\mathbf{2 1}$ as well as the corresponding tris( $\mu$-oxo) complex in the impressive enantioselective epoxidation of alkenes $\left(8-92 \%\right.$ ee). ${ }^{8}$

Wieghardt et al. had originally developed the synthesis of ( $\mu$ oxo)-bis( $\mu$-acetoxy)-dimanganese complexes of the parent macrocycle 1,4,7-trimethyl-1,4,7-triazacyclononane. ${ }^{36}$ However, using the modified method of Wieghardt and Weyhermüller ${ }^{37}$ with $(R, R)-\mathbf{1}$ failed to give any of complex 21. The difficulty in

q We are indebtited to Dr Thomas Weyhermüller (Max Planck Institute for Bioorganic chemistry, Mulheim, Germany) for providing the details of these modified conditions. ${ }^{37}$ In our hands, this process worked extremely preparing complex $\mathbf{2 1}$ is perhaps reflected in the meagre yield $(18 \%)$ reported for the preparation of the hexafluorophosphate salt of 21. ${ }^{19 a}$

Undeterred by our experiences in preparing ( $\mu$-oxo)-bis $(\mu$ acetoxy)-dimanganese complexes we then explored the preparation of copper(II) complexes of $(R, R)-\mathbf{1}$. Thus, treatment of $(R, R)$ 1 with copper(II) chloride in acetonitrile followed by addition of silver trifluoroacetate afforded blue crystals of $22(53 \%)$ (Scheme 5). ${ }^{17}$ The crystalline nature of copper(II) complex 22 allowed an X-ray analysis to be carried out: this enabled both the stereochemistry and the absolute structure to be confirmed unequivocally by single crystal diffraction (Fig. 1).॥

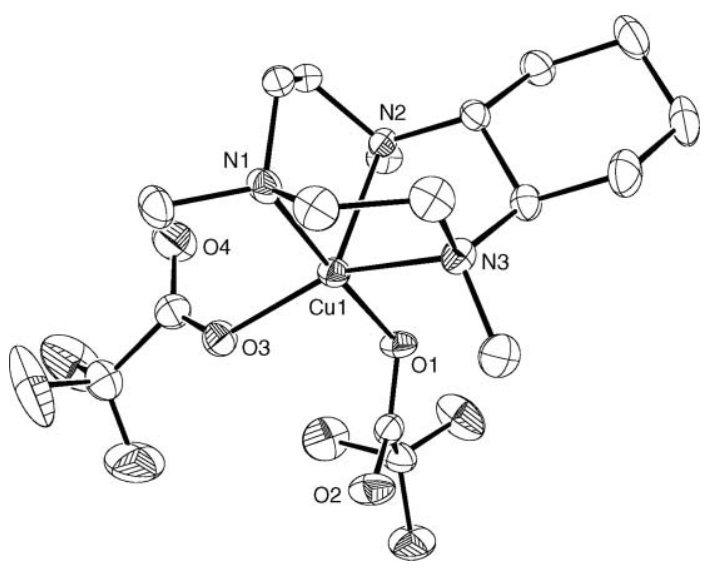

Fig. 1 ORTEP representation of complex 22. Hydrogen atoms are omitted for clarity.

The closest known structure to complex 22 is that of a copper complex of an analogous 4-oxa-1,7-diazonane (N,N,O) ligand, $\left[\mathrm{CuCl}_{2}\left(\mathrm{C}_{10} \mathrm{H}_{18} \mathrm{~N}_{2} \mathrm{O}\right)\right]$ 23. ${ }^{19 c}$

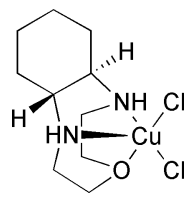

23

The complex 23 adopts a square planar structure (all angles about $\mathrm{Cu}$ are within $10^{\circ}$ of ideal 90 and $180^{\circ}$ values) with a longer contact to $\mathrm{O}$ (average $\mathrm{Cu}$... O distance $2.335 \AA$ ) giving a pseudo square pyramidal geometry. In 22, although one $\mathrm{Cu}-\mathrm{N}$ distance is longer than the others [compare 2.195(2) with 2.033(3) and 2.094(2) $\AA$ ] the difference is not so marked as in 23. In 22 there is also some distortion away from square pyramidal and towards trigonal bipyramidal geometry, with $\mathrm{O} 1$ and $\mathrm{N} 1$ axial. Complete

well for ( $\mu$-oxo)-bis( $\mu$-acetoxy)-dimanganese complexes of 1,4,7-trimethyl1,4,7-triazacyclononane $(58 \%)$. However, using $(R, R)-1$, material with a low carbon, hydrogen and nitrogen content was isolated.

\| Crystal data for 22: $\mathrm{C}_{17} \mathrm{H}_{27} \mathrm{CuF}_{6} \mathrm{~N}_{3} \mathrm{O}_{4}, M_{\mathrm{r}}=514.96$, orthorhombic, space group $P 2_{1} 2_{2} 2_{1}, a=8.3666(2), b=15.4945(3), c=16.3029(4) \AA, V=$ $2133.45(8) \AA^{3}, Z=4, \rho_{\text {calc }}=1.618 \mathrm{~g} \mathrm{~cm}^{-3}$, Mo-K $\alpha$ radiation, $\lambda=0.71073 \AA$, $\mu=1.115 \mathrm{~mm}^{-1}, T=173 \mathrm{~K} ; 30600$ reflections were collected, 4836 were unique, $R_{\text {int }} 0.077$; final refinement to convergence on $F^{2}$ with all non-H atoms anisotropic gave $R=0.0405\left(F, 3771\right.$ obs. data only) and $R_{\mathrm{w}}=0.0719$ $\left(F^{2}\right.$, all data), $\mathrm{GOF}=1.033$, for 283 refined parameters. Residual electron

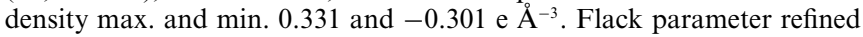
to $-0.001(1)$ indicating the correct assignment of absolute configuration. 
adoption of trigonal bipyramidal geometry is hindered by the polydentate ligand imposing small $\left(<90^{\circ}\right) \mathrm{NCuN}$ angles. The $\mathrm{N} 3 \mathrm{CuO} 3, \mathrm{~N} 2 \mathrm{CuO} 3$ and $\mathrm{N} 2 \mathrm{CuN} 3$ angles, 152.36(9), 124.75(9) and $82.87(9)^{\circ}$ respectively, emphasise the distorted nature of the resulting structure.

With an efficient synthesis of $(R, R)$-cyclohexyl macrocycle 1 developed and the preparation of the corresponding copper(II) complex 22 in hand we turned our attention to the use of the latter in the aziridination of styrene. Thus, catalyst $22(5 \mathrm{~mol} \%)$ and PhNITs ( 1 equivalent) sluggishly catalysed the aziridination of styrene 24 (10 equiv.) to afford the aziridine 25 (49\%) (Scheme 6). Disappointingly, analysis of the aziridine $\mathbf{2 5}$ by chiral HPLC indicated that racemic material had been obtained. The sluggish catalysis by $\mathbf{2 2}$ together with the production of racemic aziridine 25 suggests that $\mathrm{C}$-substitution of the azamacrocycle ring inhibits the catalysis without establishing an effective chiral pocket. This observation is supported by our experiences in the use of chiral azamacrocycles in epoxidation processes. ${ }^{11,32}$

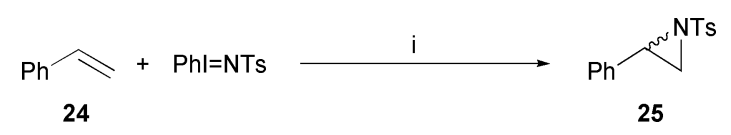

Scheme 6 Reagents and conditions: i, $5 \mathrm{~mol} \% \mathbf{2 2}, \mathrm{CH}_{3} \mathrm{CN}$, RT.

\section{Conclusions}

Classical Richman-Atkins macrocyclisation of tritosamide $\mathbf{6}$ with ethylene glycol ditosylate 7, efficiently gave the cyclohexyl-fused macrocycle 3. In contrast to published views, this indicated that macrocycle 3 was not unduly strained. Inefficiencies in the preparation of tritosamide $\mathbf{6}$ led to a re-investigation of a more direct macrocyclisation using 1,2-ditosamides. In agreement with long-standing literature precedence, initially, these cyclisations were inefficient. However, a new protocol was developed that used lithium salts of 1,2-ditosamides, generated in situ, to improve the solubility of these nucleophilic components. The improved solubility of these lithium salts of 1,2-ditosamides over their sodium salt counterparts led to dramatic improvements in the macrocyclisation yields. These improved yields were still subject to a degree of steric effects depending on the nature of the $\alpha$-substituents in the 1,2-ditosamides $\mathbf{4}$ and 16a-c. The 1,2-ditosamide 16b, lacking an $\alpha$-substituent, gave the unsubstituted 1,4,7-triazacyclononane 17b in exceptional $91 \%$ yield using our modified macrocyclisation procedure. A single methyl $\alpha$-substituent in 1,2-ditosamide 16a led to a drop in the macrocyclisation efficiency, with methyl $1,4,7$-triazacyclononane 17 a being produced in $60 \%$ yield. However, an $\alpha, \alpha^{\prime}$-disubstitution pattern in the 1,2-ditosamide was as efficient provided that the $\alpha, \alpha^{\prime}$-substituents were not too sterically demanding. So, trans-cyclohexyl-1,2-ditosamide $(R, R)$ 4 gave the cyclohexyl-fused 1,4,7-triazacyclonanone $(R, R)-3$ in $65-70 \%$ yield. In contrast, the sterically demanding $\alpha, \alpha^{\prime}$-diphenyl 1,2-ditosamide 16 failed to give any macrocycle. The efficiency of this macrocyclisation protocol allowed the synthesis of useful quantities of chiral cyclohexyl-fused azamacrocycle 3 . Subsequent deprotection, $N$-methylation of the chiral cyclohexyl-fused azamacrocycle 3 followed by copper(II) complex formation led to the preparation of the new chiral copper(II) complex 22. Although complex 22 sluggishly catalysed the aziridination of stryrene, it did so in a racemic fashion.

\section{Experimental}

\section{Synthetic studies via Route A}

(士)-4-Methyl- $N$-(2-\{[(4-methylphenyl)sulfonyl $]$ amino $\}$ cyclohexyl) benzenesulfonamide 4 . To a solution of $( \pm)$-1,2-diaminocyclohexane $9(1.20 \mathrm{~g}, 10.5 \mathrm{mmol})$, diisopropylethylamine $\left(7.3 \mathrm{~cm}^{3}\right.$, $67 \mathrm{mmol}, 6.4$ equiv. $)$ in DCM $\left(10 \mathrm{~cm}^{3}\right)$ was added $p$-toluenesulfonyl chloride $(4.0 \mathrm{~g}, 21 \mathrm{mmol}, 2$ equiv.) in batches over $30 \mathrm{~min}$ at $0{ }^{\circ} \mathrm{C}$. The reaction was continued for an additional $12 \mathrm{~h}$ at room temperature. On completion, the reaction was quenched with $2 \mathrm{M} \mathrm{HCl}\left(20 \mathrm{~cm}^{3}\right)$. The aqueous mixture was extracted with diethyl ether $\left(\times 3,20 \mathrm{~cm}^{3}\right)$ and the combined organic extracts were dried $\left(\mathrm{Na}_{2} \mathrm{SO}_{4}\right)$, filtered and evaporated to form the crude dark brown oil. Purification by column chromatography on silica (hexane-EtOAc- $\left.\mathrm{CH}_{2} \mathrm{Cl}_{2} 4: 1: 5\right)$ afforded a white solid (3.0 g, $7.1 \mathrm{mmol}, 68 \%$ ); $\mathrm{mp} 180-181{ }^{\circ} \mathrm{C}$. Found: C, 56.7; H, 6.1; N, 6.6; $\mathrm{S}, 15.2 \% ; \mathrm{MH}^{+}$423.1427. Calculated for $\mathrm{C}_{20} \mathrm{H}_{26} \mathrm{O}_{4} \mathrm{~S}_{2} \mathrm{~N}_{2}$ : C, 56.9; $\mathrm{H}, 6.2 ; \mathrm{N}, 6.6 ; \mathrm{S}, 15.2 \%$; $\mathrm{MH}^{+}$423.1412. $v_{\max }\left(\mathrm{KBr}, \mathrm{cm}^{-1}\right) 3256$ (s, NHTs), 3055 (w, $\mathrm{C}_{6} \mathrm{H}_{4}$ ), 2925 (m, CH), 2856 (m, CH), 1333 (s, $\left.\mathrm{SO}_{2} \mathrm{NH}\right), 1161\left(\mathrm{~s}, \mathrm{SO}_{2} \mathrm{NH}\right) ; \delta_{\mathrm{H}}\left(400 \mathrm{MHz}, \mathrm{CDCl}_{3}\right), 1.09(\mathrm{~m}, 4 \mathrm{H}$, $\left.2 \times \mathrm{CH}_{2}\right), 1.53\left(\mathrm{~m}, 2 \mathrm{H}, \mathrm{CH}_{2}\right), 1.81\left(\mathrm{~m}, 2 \mathrm{H}, \mathrm{CH}_{2}\right), 2.75(\mathrm{~m}, 2 \mathrm{H}$, $2 \times \mathrm{CHNHTs}), 4.98(\mathrm{~m}, 2 \mathrm{H}, 2 \times \mathrm{N} H \mathrm{Ts}), 7.31(\mathrm{~d}, J 8.3 \mathrm{~Hz}, 4 \mathrm{H}$, $\left.\mathrm{C}_{6} \mathrm{H}_{4} \mathrm{CH}_{3}\right), 7.76\left(\mathrm{~d}, J 8.3,4 \mathrm{H}, \mathrm{C}_{6} H_{4} \mathrm{CH}_{3}\right) ; \delta_{\mathrm{C}}\left(100 \mathrm{MHz}, \mathrm{CDCl}_{3}\right)$ $21.7\left(\mathrm{C}_{6} \mathrm{H}_{4} C_{3}\right), 21.9\left(\mathrm{C}_{6} \mathrm{H}_{4} C_{3}\right), 24.0\left(\mathrm{CH}_{2}\right), 26.5\left(\mathrm{CH}_{2}\right), 31.0$ $\left(\mathrm{CH}_{2}\right), 35.3\left(\mathrm{CH}_{2}\right), 54.9(\mathrm{CH}), 66.3(\mathrm{CH}), 127.3(4 \times \mathrm{ArCH}), 129.7$ $(4 \times \operatorname{ArCH}), 139.6(2 \times \operatorname{ArC}), 143.3(2 \times \operatorname{ArC})$.

4-Methyl- $N$-(1-methyl-2-\{ [(4-methylphenyl)sulfonyl]amino $\}$ ethyl)benzenesulfonamide 16a. The title compound 16a was prepared in a similar manner to $\mathbf{4}$ using $( \pm)$-1,2-propanediamine 15a $\left(2 \mathrm{~cm}^{3}, 1.74 \mathrm{~g}, 23.5 \mathrm{mmol}\right)$, triethylamine $\left(17 \mathrm{~cm}^{3}, 12.34 \mathrm{~g}\right.$, $122 \mathrm{mmol}, 5.2$ equiv.) and $p$-toluenesulfonyl chloride $(10.00 \mathrm{~g}$, $52.6 \mathrm{mmol} \mathrm{mmol})$. The crude product was filtered through silica $\left(6 \times 5 \mathrm{~cm}^{3}\right)$ which gave a gum that was precipitated from ethanol using diethyl ether. Recrystallisation from ethanol gave the title compound 16a as large long needles (7.73 g, $20.2 \mathrm{mmol}, 86 \%$ ); mp 106-108 ${ }^{\circ} \mathrm{C}$ (lit. ${ }^{38} 103-104{ }^{\circ} \mathrm{C}$ ). Found: C, 53.4; H, 5.8; N, 7.2; $\mathrm{S}, 16.7 \%$; $\mathrm{MH}^{+}$383.1099. Calculated for $\mathrm{C}_{17} \mathrm{H}_{22} \mathrm{~N}_{2} \mathrm{O}_{4} \mathrm{~S}_{2}$ : C, 53.4; $\mathrm{H}, 5.8 ; \mathrm{N}, 7.3 ; \mathrm{S}, 16.8 \%$; $\mathrm{MH}^{+} 383.1099 . v_{\max }\left(\mathrm{KBr}, \mathrm{cm}^{-1}\right) 3303$ (s, NHTs), 2925 (m, CH), 2978 (w, CH), 1598 (w, $\mathrm{C}_{6} \mathrm{H}_{4}$ ), 1322 (s, $\left.\mathrm{SO}_{2} \mathrm{NH}\right), 1159\left(\mathrm{~s}, \mathrm{SO}_{2} \mathrm{NH}\right), 814\left(\mathrm{~s}, \mathrm{C}_{6} \mathrm{H}_{4}\right) ; \delta_{\mathrm{H}}\left(400 \mathrm{MHz}, \mathrm{CDCl}_{3}\right)$ $0.97\left(\mathrm{~d}, J 6.4 \mathrm{~Hz}, 3 \mathrm{H}, \mathrm{CH}_{3}\right), 2.40\left(\mathrm{~s}, 6 \mathrm{H}, 2 \times \mathrm{H} \mathrm{CH}_{3}\right), 2.82-2.88$ $(\mathrm{m}, 1 \mathrm{H}, \mathrm{CHH}), 2.91-2.98(\mathrm{~m}, 1 \mathrm{H}, \mathrm{CH} H), 3.27-3.36(\mathrm{~m}, 1 \mathrm{H}, \mathrm{CH})$, $5.23(\mathrm{~d}, J 7.6,1 \mathrm{H}, \mathrm{NH}), 5.36(\mathrm{~d}, J 6.4,1 \mathrm{H}, \mathrm{NH}), 7.25-7.28(\mathrm{~m}, 4 \mathrm{H}$, $\left.\mathrm{C}_{6} \mathrm{H}_{4} \mathrm{CH}_{3}\right), 7.65-7.74\left(\mathrm{~m}, 4 \mathrm{H}, \mathrm{C}_{6} H_{4} \mathrm{CH}_{3}\right) ; \delta_{\mathrm{C}}\left(100 \mathrm{MHz}, \mathrm{CDCl}_{3}\right)$ $18.8\left(\mathrm{CH}_{3}\right), 21.6\left(\mathrm{CH}_{3}\right), 21.7\left(\mathrm{CH}_{3}\right), 48.5\left(\mathrm{CH}_{2} \mathrm{~N}\right), 49.7(\mathrm{CHN})$, 127.2, 127.3, 129.9, 130.0 (all $2 \times \mathrm{C}_{6} \mathrm{H}_{4} \mathrm{CH}_{3}$ ), 136.9 and 137.4 (both $\operatorname{ArC}$ ), 143.6 and 143.8 (both $\operatorname{ArC}$ ).

4-Methyl-N-(2-\{I(4-methylphenyl)sulfonyl]amino\} ethyl)benzenesulfonamide 16b. The title compound $\mathbf{1 6}$ b was prepared in a similar manner to 4 using ethylenediamine $\mathbf{1 5 b}\left(3 \mathrm{~cm}^{3}, 44 \mathrm{mmol}\right)$, triethylamine $\left(32 \mathrm{~cm}^{3}, 0.224 \mathrm{~mol}\right)$ and $p$-toluenesulfonyl chloride (18.8 g, $98 \mathrm{mmol})$. Addition of diethyl ether gave a precipitate that was collected by filtration and washed with hexane. The crude product 16b $(12.60 \mathrm{~g}, 0.034 \mathrm{~mol}, 76 \%)$ was pure enough for the next step; mp $163-164{ }^{\circ} \mathrm{C}$ (lit. ${ }^{24} 162-164{ }^{\circ} \mathrm{C}$ ). Found: C, 52.1; $\mathrm{H}, 5.5 ; \mathrm{N}, 7.8 ; \mathrm{S}, 17.4 \%$. Calculated for $\mathrm{C}_{16} \mathrm{H}_{20} \mathrm{~N}_{2} \mathrm{O}_{4} \mathrm{~S}_{2}$ : C, 52.2; $\mathrm{H}, 5.5 ; \mathrm{N}, 7.6 ; \mathrm{S}, 17.4 \%$. $v_{\max }\left(\mathrm{KBr}, \mathrm{cm}^{-1}\right) 3289$ (s, TsNH), 3076 
(w, $\left.\mathrm{C}_{6} \mathrm{H}_{4}\right), 2928,(\mathrm{~m}, \mathrm{CH}), 2884(\mathrm{~m}, \mathrm{CH}), 1333,\left(\mathrm{~s}, \mathrm{SO}_{2} \mathrm{NH}\right), 1156$ (s, $\left.\mathrm{SO}_{2} \mathrm{NH}\right) ; \delta_{\mathrm{H}}\left(400 \mathrm{MHz}, \mathrm{CDCl}_{3}\right) 2.37\left(\mathrm{~s}, 6 \mathrm{H}, \mathrm{C}_{6} \mathrm{H}_{4} \mathrm{CH}_{3}\right), 2.70$ $\left(\mathrm{s}, 4 \mathrm{H}, \mathrm{CH}_{2}\right), 7.37\left(\mathrm{~d}, J 8.0 \mathrm{~Hz}, 4 \mathrm{H}, \mathrm{C}_{6} H_{4}\right), 7.60(\mathrm{~d}, J 8.0,4 \mathrm{H}$, $\left.\mathrm{C}_{6} \mathrm{H}_{4}\right) ;{ }^{13} \mathrm{C} \mathrm{NMR}\left(\mathrm{CD}_{3} \mathrm{SOCD}_{3}\right) \delta_{\mathrm{C}} 21.4\left(\mathrm{C}_{6} \mathrm{H}_{4} \mathrm{CH}_{3}\right), 42.6\left(\mathrm{CH}_{2} \mathrm{~N}\right)$, 126.8, $130.1\left(\right.$ all $\left.C_{6} \mathrm{H}_{4} \mathrm{CH}_{3}\right), 137.7,143.2$ (both $\mathrm{ArC}$ ).

4-Methyl- $N$-((1R,2R)-2-\{I(4-methylphenyl)sulfonyl]amino $\}-1,2-$ diphenylethyl)benzenesulfonamide 16c. The title compound 16c was prepared according to the method of Corey et al. ${ }^{39}$ using $(1 R, 2 R)$-1,2-diphenyl-1,2-ethanediamine $15 \mathrm{c}(1.08 \mathrm{~g}, 5.07 \mathrm{mmol})$, triethylamine $\left(3.5 \mathrm{~cm}^{3}, 25.1 \mathrm{mmol}\right), N, N$-dimethylaminopyridine $(25 \mathrm{mg}, 0.2 \mathrm{mmol})$ and $p$-toluenesulfonyl chloride $(2.18 \mathrm{~g}$, $11.4 \mathrm{mmol})$. Recrystallisation from ethanol gave the title compound $16 \mathbf{c}$ as fine white needles $(2.35 \mathrm{~g}, 4.5 \mathrm{mmol}, 89 \%) ; \mathrm{mp}$ $209-210{ }^{\circ} \mathrm{C}\left(\right.$ lit. $\left.^{40} 202{ }^{\circ} \mathrm{C}\right) ;[\alpha]_{\mathrm{D}}=40.5\left(c=1.76, \mathrm{CHCl}_{3}\right)\left(\right.$ lit. $^{39}$ $[a]_{\mathrm{D}}=43.9\left(c=1.74, \mathrm{CHCl}_{3}\right)$. Found: $\mathrm{C}, 64.8 ; \mathrm{H}, 5.3 ; \mathrm{N}, 5.6$; S, $13.4 \%$. Calculated for $\mathrm{C}_{28} \mathrm{H}_{28} \mathrm{~N}_{2} \mathrm{O}_{4} \mathrm{~S}_{2}: \mathrm{C}, 64.6 ; \mathrm{H}, 5.4 ; \mathrm{N}, 5.4$; $\mathrm{S}, 12.3 \% . \delta_{\mathrm{H}}\left(400 \mathrm{MHz}, \mathrm{CDCl}_{3}\right) 2.31\left(\mathrm{~s}, 6 \mathrm{H}, 2 \times \mathrm{C}_{6} \mathrm{H}_{4} \mathrm{CH}_{3}\right)$, 4.51-4.56 (ABX m, 2H, $2 \times \mathrm{CHNH}), 5.89-5.95(\mathrm{ABX} \mathrm{m} \mathrm{2H}$, $2 \times \mathrm{NH}), 6.71\left(\mathrm{~d}, J 8.0 \mathrm{~Hz}, 4 \mathrm{H}, \mathrm{C}_{6} H_{4} \mathrm{CH}_{3}\right), 6.99-7.05(\mathrm{~m}, 10 \mathrm{H}$, $\left.\mathrm{C}_{6} H_{5}\right), 7.47\left(\mathrm{~d}, J 8.0,4 \mathrm{H}, \mathrm{C}_{6} H_{4} \mathrm{CH}_{3}\right) ; \delta_{\mathrm{C}}\left(100 \mathrm{MHz}, \mathrm{CDCl}_{3}\right) 21.6$ $\left(2 \times \mathrm{C}_{6} \mathrm{H}_{4} \mathrm{CH}_{3}\right), 62.5(2 \times \mathrm{CHNH}), 127.3(4 \times \mathrm{ArCH}), 127.7$ $(2 \times \mathrm{ArCH}), 127.8(4 \times \mathrm{ArCH}), 128.2(4 \times \mathrm{ArCH}), 129.0(4 \times$ $\operatorname{ArCH}), 136.5(2 \times \operatorname{ArC}), 137.2(2 \times \operatorname{ArC}), 143.3(2 \times \operatorname{ArC})$. Using the chiral shift reagent $\mathrm{Eu}(\mathrm{hfc})_{2}$ indicated an ee $\geqslant 99 \%$.

$(1 R, 2 R)-1,2-C y c l o h e x a n e d i a m i n i u m \quad(2 R, 3 R)$-2,3-dihydroxybutanedioate 14. The title compound 14 was prepared according to the method of Jacobsen and co-workers. ${ }^{28}$ Thus, using $( \pm)-1,2-$ cyclohexanediamine $9\left(24 \mathrm{~cm}^{3}, 0.2 \mathrm{~mol}\right)$, L-tartaric acid $(15.00 \mathrm{~g}$, $0.1 \mathrm{~mol})$ and glacial acetic acid $\left(10 \mathrm{~cm}^{3}, 0.175 \mathrm{~mol}\right)$ gave the title compound 14 as a white solid $(21.73 \mathrm{~g}, 82 \mathrm{mmol}, 85 \%)$. An analytical sample was obtained by recrystallisation from water, which afforded colourless plates; $\mathrm{mp} 252.5-256{ }^{\circ} \mathrm{C}$ (lit. ${ }^{40} 252-$ $\left.255^{\circ} \mathrm{C}\right) ;[a]_{\mathrm{D}}=+12.2\left(c=1, \mathrm{H}_{2} \mathrm{O}\right)\left[\right.$ lit. $\left.^{23}[\alpha]_{\mathrm{D}}=+12.4\left(c=2, \mathrm{H}_{2} \mathrm{O}\right)\right]$. Found: C, 45.5; H, 7.6; N, 10.4\%. Calculated for $\mathrm{C}_{10} \mathrm{H}_{20} \mathrm{~N}_{2} \mathrm{O}_{6}$ : C, 45.5; H, 7.6; N, 10.6\%.

4-Methyl- $N$-((1R,2R)-2-\{[(4-methylphenyl)sulfonyl]amino $\}$ cyclohexyl)benzenesulfonamide $(\boldsymbol{R}, \boldsymbol{R})-\mathbf{4}$. To a stirred solution of $(1 R, 2 R)$-1,2-cyclohexanediaminium $\quad(2 R, 3 R)$-2,3-dihydroxybutanedioate $14(11.20 \mathrm{~g}, 42.4 \mathrm{mmol})$ in distilled water $\left(150 \mathrm{~cm}^{3}\right)$ and sodium hydroxide $(7.10 \mathrm{~g}, 177.7 \mathrm{mmol})$ at $0{ }^{\circ} \mathrm{C}$ under a nitrogen atmosphere was added dropwise a solution of $p$ toluenesulfonyl chloride $(16.99 \mathrm{~g}, 89.1 \mathrm{mmol})$ in dichloromethane $\left(100 \mathrm{~cm}^{3}\right)$ over a $1 \mathrm{~h}$ period. The reaction mixture was allowed to warm to room temperature and then stirred for $18 \mathrm{~h}$. At the completion of this period the phases were separated and the aqueous phase was extracted with dichloromethane $(2 \times$ $\left.100 \mathrm{~cm}^{3}\right)$. The combined organic extracts were washed with brine $\left(5 \mathrm{~cm}^{3}\right)$, dried $\left(\mathrm{Na}_{2} \mathrm{SO}_{4}\right)$, filtered and evaporated to afford a white foam $(20.54 \mathrm{~g})$. Recrystallisation from methanol gave the title compound $(15.30 \mathrm{~g}, 36.14 \mathrm{mmol}, 85 \%)$ as a colourless microcrystalline solid; mp $172-184{ }^{\circ} \mathrm{C}\left(\right.$ lit. $\left.^{41}{ }^{167-168}{ }^{\circ} \mathrm{C}\right) ;[\alpha]_{\mathrm{D}}=$ $12.2\left(c=2.04, \mathrm{CHCl}_{3}\right)\left[\mathrm{lit}^{40}[a]_{\mathrm{D}}=9.76\left(c=2.06, \mathrm{CHCl}_{3}\right)\right]$. Found: C, 57.0; H, 6.1; N, 6.8; $\mathrm{S}, 15.1 \%$. Calculated for $\mathrm{C}_{20} \mathrm{H}_{26} \mathrm{~N}_{2} \mathrm{O}_{4} \mathrm{~S}_{2}: \mathrm{C}$, 56.9; H, 6.2; N, 6.6; S, 15.2\%. $v_{\max }\left(\mathrm{KBr}, \mathrm{cm}^{-1}\right) 3286$ (s, TsNH), $3065\left(\mathrm{w}, \mathrm{C}_{6} \mathrm{H}_{4}\right), 2928(\mathrm{~m}, \mathrm{CH}), 2870(\mathrm{~m}, \mathrm{CH}), 1326\left(\mathrm{~s}, \mathrm{SO}_{2} \mathrm{NH}\right)$, $1162\left(\mathrm{~s}, \mathrm{SO}_{2} \mathrm{NH}\right) ; \delta_{\mathrm{H}}\left(400 \mathrm{MHz}, \mathrm{CDCl}_{3}\right) 1.05-1.14(\mathrm{~m}, 4 \mathrm{H}, 2 \times$
$\left.\mathrm{CH}_{2}\right), 1.53-1.55\left(\mathrm{~m}, 2 \mathrm{H}, \mathrm{CH}_{2}\right), 1.81-1.84\left(\mathrm{~m}, 2 \mathrm{H}, \mathrm{CH}_{2}\right), 2.42$ (s, $\left.6 \mathrm{H}, 2 \times \mathrm{C}_{6} \mathrm{H}_{4} \mathrm{CH}_{3}\right), 2.75-2.77\left(\mathrm{~m}, 2 \mathrm{H}, 2 \times \mathrm{ArSO}_{2} \mathrm{NHCH}\right)$, 4.95-5.00 (m, $\left.2 \mathrm{H}, 2 \times \mathrm{ArSO}_{2} \mathrm{NHCH}\right), 7.30(\mathrm{~d}, J 8.3 \mathrm{~Hz}, 4 \mathrm{H}$, $\left.2 \times \mathrm{C}_{6} H_{4} \mathrm{CH}_{3}\right), 7.75\left(\mathrm{~d}, J 8.3,4 \mathrm{H}, 2 \times \mathrm{C}_{6} H_{4} \mathrm{CH}_{3}\right) ; \delta_{\mathrm{C}}(400 \mathrm{MHz}$, $\left.\mathrm{CDCl}_{3}\right) 21.7\left(2 \times \mathrm{C}_{6} \mathrm{H}_{4} \mathrm{CH}_{3}\right), 24.3\left(2 \times \mathrm{CCH}_{2} \mathrm{C}\right), 33.3(2 \times$ $\left.\mathrm{CCH}_{2} \mathrm{C}\right), 56.7(2 \times \mathrm{NHCH}), 127.4\left(4 \times \mathrm{C}_{6} \mathrm{H}_{4} \mathrm{CH}_{3}\right), 129.9(4 \times$ $\left.\mathrm{C}_{6} \mathrm{H}_{4} \mathrm{CH}_{3}\right), 137.2(2 \times \mathrm{ArC}), 143.7(2 \times \mathrm{ArC})$.

2-[I(4-Methylphenyl)sulfonyl](3-\{[(4-methylphenyl)sulfonyl]oxy $\}$ propyl)aminolethyl-4-methylbenzenesulfonate 5 . The title compound was prepared according to the method of Searle and $\mathrm{Geue}^{24}$ using diethanolamine $(1.00 \mathrm{~g}, 9.5 \mathrm{mmol})$ and $p$ toluenesulfonyl chloride $(4.00 \mathrm{~g}, 21 \mathrm{mmol})$ which gave a crude dark brown oil. Purification by column chromatography on silica (hexane-EtOAc- $\left.\mathrm{CH}_{2} \mathrm{Cl}_{2} 4: 1: 5\right)$ afforded a white solid $(3.20 \mathrm{~g}$, $5.7 \mathrm{mmol}, 60 \%$ ); $\mathrm{mp} 94-96^{\circ} \mathrm{C}$ (lit. $.^{24} 96-98^{\circ} \mathrm{C}$ ). Found: C, 53.1; H, 5.2; N, 2.5; S, 16.7\%; $\mathrm{MH}^{+} 568.1144$. Calculated for $\mathrm{C}_{25} \mathrm{H}_{30} \mathrm{O}_{8} \mathrm{~S}_{3} \mathrm{~N}$ : C, 52.9; H, 5.2; N, 2.5; S, 16.9\%; $\mathrm{MH}^{+} 568.1134 . v_{\max }\left(\mathrm{KBr}, \mathrm{cm}^{-1}\right)$ $3062\left(\mathrm{w}, \mathrm{C}_{6} \mathrm{H}_{4}\right), 2952(\mathrm{~m}, \mathrm{CH}), 1357\left(\mathrm{~s}, \mathrm{SO}_{2} \mathrm{NH}\right), 1174\left(\mathrm{~s}, \mathrm{SO}_{2} \mathrm{OR}\right)$, $1158\left(\mathrm{~s}, \mathrm{SO}_{2} \mathrm{NH}\right) ; \delta_{\mathrm{H}}\left(400 \mathrm{MHz}, \mathrm{CDCl}_{3}\right) 2.42\left(\mathrm{~s}, 3 \mathrm{H}, \mathrm{C}_{6} \mathrm{H}_{4} \mathrm{CH}_{3}\right)$, $2.47\left(\mathrm{~s}, 6 \mathrm{H}, \mathrm{C}_{6} \mathrm{H}_{4} \mathrm{CH}_{3}\right), 3.38$ (t, $\left.J 5.9 \mathrm{~Hz}, 4 \mathrm{H}, \mathrm{CH}_{2} \mathrm{NTs}\right), 4.12$ (t, $\left.J 5.9,4 \mathrm{H}, \mathrm{CH}_{2} \mathrm{OTs}\right), 7.29\left(\mathrm{~d}, J 8.0,2 \mathrm{H}, \mathrm{C}_{6} H_{4} \mathrm{CH}_{3}\right) ; 7.35(\mathrm{~d}, J$ $\left.8.0,4 \mathrm{H}, \mathrm{C}_{6} H_{4} \mathrm{CH}_{3}\right) ; 7.63\left(\mathrm{~d}, J 8.0,2 \mathrm{H}, \mathrm{C}_{6} H_{4} \mathrm{CH}_{3}\right) ; 7.78(\mathrm{~d}, J$ 8.0, $\left.4 \mathrm{H}, \mathrm{C}_{6} \mathrm{H}_{4} \mathrm{CH}_{3}\right) ; \delta_{\mathrm{C}}\left(100 \mathrm{MHz}, \mathrm{CDCl}_{3}\right) 21.7\left(\mathrm{C}_{6} \mathrm{H}_{4} \mathrm{CH}_{3}\right), 21.8(2 \times$ $\left.\mathrm{C}_{6} \mathrm{H}_{4} \mathrm{CH}_{3}\right), 48.7\left(2 \times \mathrm{CH}_{2} \mathrm{NTs}\right), 68.5\left(2 \times \mathrm{CH}_{2} \mathrm{OTs}\right), 127.5(2 \times$ $\mathrm{ArCH}), 128.2(4 \times \operatorname{ArCH}), 130.1(4 \times \operatorname{ArCH}), 130.2(2 \times \mathrm{ArCH})$, $132.7(2 \times \operatorname{ArC}), 135.5(\operatorname{ArC}), 144.4(\operatorname{ArC}), 145.4(2 \times \operatorname{ArC})$.

2-[I(4-Nitrophenyl)sulfonyl](2-\{[(4-nitrophenyl)sulfonyl]oxy $\}$ ethyl)amino]ethyl 3-nitrobenzenesulfonate 18. To a stirred solution of diethanolamine $(587 \mathrm{mg}, 5.69 \mathrm{mmol})$ and triethylamine $\left(2.8 \mathrm{~cm}^{3}, 20 \mathrm{mmol}\right)$ in anhydrous THF $\left(14 \mathrm{~cm}^{3}\right)$ at $0{ }^{\circ} \mathrm{C}$ under a nitrogen atmosphere was added portionwise, 4-nitrobenzenesulfonyl chloride $(4.10 \mathrm{~g}, 18.7 \mathrm{mmol})$. This mixture was stirred at $0{ }^{\circ} \mathrm{C}$ for $1 \mathrm{~h}$ then at room temperature for $18 \mathrm{~h}$. At the conclusion of this period the reaction mixture was concentrated at reduced pressure $(20 \mathrm{~mm} \mathrm{Hg})$. The residue was dissolved in dichloromethane $\left(20 \mathrm{~cm}^{3}\right)$, washed with water $\left(25 \mathrm{~cm}^{3}\right)$, dried $\left(\mathrm{Na}_{2} \mathrm{SO}_{4}\right)$, filtered and evaporated to afford an orange solid. Recrystallisation from methanol-THF gave the title compound 18 ( $2.42 \mathrm{~g}, 3.66 \mathrm{mmol}$, $65 \%$ ) as colourless needles; mp $131-134{ }^{\circ} \mathrm{C}$. Found: C, 40.1; $\mathrm{H}, 2.9 ; \mathrm{N}, 8.3 \% ; \mathrm{MNH}_{4}{ }^{+}$678.0482. $\mathrm{C}_{22} \mathrm{H}_{20} \mathrm{~N}_{4} \mathrm{O}_{14} \mathrm{~S}_{3}$ requires: $\mathrm{C}$, 40.0; H, 3.0; N, 8.5\%; $\mathrm{MNH}_{4}{ }^{+}$678.0476. $v_{\max }\left(\mathrm{KBr}, \mathrm{cm}^{-1}\right) 3108$ and 3041 (w, $\left.\mathrm{C}_{6} \mathrm{H}_{4}\right), 2936$ (w, CH), $1530\left(\mathrm{~s}, \mathrm{C}_{6} \mathrm{H}_{4} \mathrm{NO}_{2}\right), 1366$ (s, $\left.\mathrm{SO}_{2} \mathrm{~N}\right), 1352\left(\mathrm{~s}, \mathrm{OSO}_{2}\right), 1312(\mathrm{~s}), 1184\left(\mathrm{~s}, \mathrm{SO}_{2}\right) ; \delta_{\mathrm{H}}(400 \mathrm{MHz}$, $\left.\mathrm{CD}_{3} \mathrm{NO}_{2}\right) 3.54-3.62\left(\mathrm{~m}, 4 \mathrm{H}, 2 \times \mathrm{CH}_{2} \mathrm{OSO}_{2}\right), 4.23-4.31(\mathrm{~m}, 4 \mathrm{H}$, $\left.2 \times \mathrm{CH}_{2} \mathrm{NSO}_{2}\right), 8.01\left(\mathrm{~d}, J 8.0 \mathrm{~Hz}, 2 \mathrm{H}, \mathrm{C}_{6} H_{4} \mathrm{SO}_{2} \mathrm{~N}\right), 8.13(\mathrm{~d}, J 8.0$, $\left.4 \mathrm{H}, \mathrm{NO}_{2} \mathrm{C}_{6} H_{4} \mathrm{SO}_{2} \mathrm{O}\right), 8.34\left(\mathrm{~d}, J 8.0,2 \mathrm{H}, \mathrm{NO}_{2} \mathrm{C}_{6} H_{4} \mathrm{SO}_{2} \mathrm{~N}\right), 8.44$ (d, $J$ 8.0, 4H, $\left.\mathrm{NO}_{2} \mathrm{C}_{6} \mathrm{H}_{4} \mathrm{SO}_{2} \mathrm{O}\right) ; \delta_{\mathrm{C}}\left(100 \mathrm{MHz}, \mathrm{CD}_{3} \mathrm{NO}_{2}\right) 49.1(2 \times$ $\left.\mathrm{CH}_{2} \mathrm{NSO}_{2}\right), 70.5\left(4 \times \mathrm{CH}_{2} \mathrm{OSO}_{2}\right), 125.9\left(2 \times C_{6} \mathrm{H}_{4}\right), 126.0(4 \times$ $\left.C_{6} \mathrm{H}_{4}\right), 130\left(2 \times C_{6} \mathrm{H}_{4}\right), 130.8\left(2 \times C_{6} \mathrm{H}_{4}\right), 142.1(2 \times \mathrm{ArC}), 145.5$, 152 and $152.7($ all $\operatorname{ArC})$.

( \pm )-1,4,7-Tris[(4-methylphenyl)sulfonyl]dodecahydro-1 $H$-1,4,7benzotriazonine 3 .

(a) Method A (potassium carbonate in DMF) (Table 1, entry 1). To ( \pm )-4-methyl- $N$-(2-\{[(4-methylphenyl)sulfonyl]amino $\}$ cyclohexyl) benzenesulfonamide $4(600 \mathrm{mg}, 1.4 \mathrm{mmol})$ in DMF $\left(19 \mathrm{~cm}^{3}\right)$ was added potassium carbonate $(461 \mathrm{mg}, 3.3 \mathrm{mmol})$. The resulting suspension was heated to $50^{\circ} \mathrm{C}$ for $1 \mathrm{~h}$. On completion 
of this period a solution of 2-[[(4-methylphenyl)sulfonyl](3-\{[(4-methylphenyl)sulfonyl]oxy\} propyl)amino]ethyl-4-methylbenzenesulfonate $5(990 \mathrm{mg}, 1.7 \mathrm{mmol})$ in DMF $\left(10 \mathrm{~cm}^{3}\right)$ was added dropwise over $24 \mathrm{~h}$. The DMF was removed under reduced pressure $(12 \mathrm{~mm} \mathrm{Hg})$ and the residue was dissolved in dichloromethane $\left(15 \mathrm{~cm}^{3}\right)$. The organic layer was washed with water $\left(\times 2,20 \mathrm{~cm}^{3}\right)$, dried $\left(\mathrm{Na}_{2} \mathrm{SO}_{4}\right)$, filtered and evaporated to give a off-white solid $(520 \mathrm{mg})$. The off-white solid was dissolved in ethanol $\left(10 \mathrm{~cm}^{3}\right)$ and heated to reflux for $2 \mathrm{~h}$. The white precipitate that formed was removed by filtration, washed with ethanol $\left(10 \mathrm{~cm}^{3}\right)$ and dried under reduced pressure $(0.1 \mathrm{~mm} \mathrm{Hg})$ to give the title macrocycle $( \pm)-3$ as a white solid (162 mg, $0.25 \mathrm{mmol}, 18 \%)$; mp $260-262{ }^{\circ} \mathrm{C}$. Found: C, 57.7; H, 5.9; N, 6.2; S, 14.9\%; $\mathrm{MH}^{+}$ 646.2093. $\mathrm{C}_{31} \mathrm{H}_{39} \mathrm{O}_{6} \mathrm{~S}_{3} \mathrm{~N}_{3}$ requires: $\mathrm{C}, 57.7 ; \mathrm{H}, 6.1 ; \mathrm{N}, 6.5 ; \mathrm{S}, 14.9 \%$; $\mathrm{MH}^{+}$646.2079. $v_{\max }\left(\mathrm{KBr}, \mathrm{cm}^{-1}\right) 3065\left(\mathrm{w}, \mathrm{C}_{6} \mathrm{H}_{4}\right), 2928(\mathrm{~m}, \mathrm{CH})$, $2865(\mathrm{~m}, \mathrm{CH}), 1326\left(\mathrm{~s}, \mathrm{SO}_{2} \mathrm{NH}\right), 1153\left(\mathrm{~s}, \mathrm{SO}_{2} \mathrm{NH}\right) ; \delta_{\mathrm{H}}(400 \mathrm{MHz}$, $\left.\mathrm{CDCl}_{3}\right) 1.14\left(\mathrm{~m}, 2 \mathrm{H}, \mathrm{CH}_{2}\right), 1.27\left(\mathrm{~m}, 2 \mathrm{H}, \mathrm{CH}_{2}\right), 1.58\left(\mathrm{~m}, 2 \mathrm{H}, \mathrm{CH}_{2}\right)$, $1.79\left(\mathrm{~m}, 1 \mathrm{H}, \mathrm{CH}_{2}\right), 2.17\left(\mathrm{~m}, 1 \mathrm{H}, \mathrm{CH}_{2}\right), 2.35\left(\mathrm{~s}, 3 \mathrm{H}, \mathrm{C}_{6} \mathrm{H}_{4} \mathrm{CH}_{3}\right)$, $2.42\left(\mathrm{~s}, 6 \mathrm{H}, \mathrm{C}_{6} \mathrm{H}_{4} \mathrm{CH}_{3}\right), 2.62\left(\mathrm{~m}, 1 \mathrm{H}, \mathrm{CH}_{2} \mathrm{NTs}\right), 3.07(\mathrm{~m}, 1 \mathrm{H}$, $\mathrm{CH}_{2} \mathrm{NTs}$ ), 3.28 (m, $\left.3 \mathrm{H}, \mathrm{CH}_{2} \mathrm{NTs}\right), 3.48$ (m, $\left.3 \mathrm{H}, \mathrm{CH}_{2} \mathrm{NTs}\right), 3.75$ $(\mathrm{m}, 1 \mathrm{H}, \mathrm{C} H \mathrm{NTs}), 4.89(\mathrm{~m}, 1 \mathrm{H}, \mathrm{C} H \mathrm{NTs}), 7.29\left(\mathrm{~m}, 6 \mathrm{H}, \mathrm{C}_{6} \mathrm{H}_{4} \mathrm{CH}_{3}\right)$, $7.61\left(\mathrm{~d}, J 8.3 \mathrm{~Hz}, 2 \mathrm{H}, \mathrm{C}_{6} H_{4} \mathrm{CH}_{3}\right), 7.76\left(\mathrm{~m}, 2 \mathrm{H}, \mathrm{C}_{6} H_{4} \mathrm{CH}_{3}\right), 8.00$ $\left(\mathrm{m}, 2 \mathrm{H}, \mathrm{C}_{6} H_{4} \mathrm{CH}_{3}\right) ; \delta_{\mathrm{C}}\left(100 \mathrm{MHz}, \mathrm{CDCl}_{3}\right) 21.7\left(3 \times \mathrm{C}_{6} \mathrm{H}_{4} \mathrm{CH}_{3}\right)$, $24.7\left(\mathrm{CH}_{2}\right), 26.1\left(\mathrm{CH}_{2}\right), 29.0\left(\mathrm{CH}_{2}\right), 30.3\left(\mathrm{CH}_{2}\right), 47.1\left(\mathrm{CH}_{2} \mathrm{NTs}\right)$, $52.4\left(\mathrm{CH}_{2} \mathrm{NTs}\right), 55.0\left(\mathrm{CH}_{2} \mathrm{NTs}\right), 55.8\left(\mathrm{CH}_{2} \mathrm{NTs}\right), 60.2(\mathrm{CHNTs})$, 68.2 (CHNTs), $127.3(2 \times \operatorname{ArCH}), 127.9(2 \times \operatorname{ArCH}), 128.7(2 \times$ $\operatorname{ArCH}), 129.7(2 \times \operatorname{ArCH}), 129.9(4 \times \operatorname{ArCH}), 130.1(2 \times \operatorname{ArC})$, $135.1(\operatorname{ArC}), 137.5(\operatorname{ArC}), 143.6(\operatorname{ArC}), 144.2(\operatorname{ArC})$.

(b) Method B (sodium ethoxide in ethanol then DMF) (Table 1, entry 2$)^{19 a}$. To a stirred suspension of ( \pm )-4-methyl- $N$ - $(2-\{[(4-$ methylphenyl)sulfonyl]amino\}cyclohexyl)benzenesulfonamide 4 (500 mg, $1.2 \mathrm{mmol})$ in anhydrous ethanol $\left(2 \mathrm{~cm}^{3}\right)$ at reflux under nitrogen was added a solution of sodium ethoxide $(170 \mathrm{mg}$, $2.6 \mathrm{mmol}$ ) in ethanol $\left(1 \mathrm{~cm}^{3}\right)$. The mixture became homogenous then a white precipitate formed which was diluted with a further portion of ethanol $\left(10 \mathrm{~cm}^{3}\right)$. The resulting suspension was boiled for $30 \mathrm{~min}$ and then cooled to room temperature. The precipitate was collected by filtration and dried under high vacuum $(0.1 \mathrm{~mm}$ $\mathrm{Hg}$ ) which gave the crude disodium salt (491 mg, $1.05 \mathrm{mmol}, 89 \%$ ) a white papery solid.

The above disodium salt (491 $\mathrm{mg}, 1.05 \mathrm{mmol}$ ) was suspended in anhydrous DMF $\left(7 \mathrm{~cm}^{3}\right)$ under a nitrogen atmosphere and heated to $100{ }^{\circ} \mathrm{C}$. To this suspension was added a solution of 2-[[(4-methylphenyl)sulfonyl](3-\{[(4-methylphenyl)sulfonyl]oxy\}propyl)amino]ethyl-4-methylbenzenesulfonate $\mathbf{5} \quad(719 \quad \mathrm{mg}$, $1.27 \mathrm{mmol})$ in DMF $\left(3.5 \mathrm{~cm}^{3}\right)$ over a $4 \mathrm{~h}$ period. The resulting solution was stirred at $100^{\circ} \mathrm{C}$ for 7 days, whereupon, the volatiles were removed $(0.1 \mathrm{~mm} \mathrm{Hg})$. The residue was partitioned between dichloromethane $\left(10 \mathrm{~cm}^{3}\right)$ and dilute hydrochloric acid $(0.23 \mathrm{M}$, $13 \mathrm{~cm}^{3}$ ) and the layers were separated. The aqueous phase was extracted with dichloromethane $\left(2 \times 10 \mathrm{~cm}^{3}\right)$ and the combined organic layers were dried $\left(\mathrm{Na}_{2} \mathrm{SO}_{4}\right)$, filtered and evaporated to afford an oil. This oil was dissolved in ethanol $\left(10 \mathrm{~cm}^{3}\right)$ under a nitrogen atmosphere and this solution was heated under reflux for $2 \mathrm{~h}$ to afford a white solid. Filtration afforded the title macrocycle $( \pm)-\mathbf{3}$ as a white microcrystalline solid (153 $\mathrm{mg}, 0.24 \mathrm{mmol}, 23 \%)$. The physical and spectroscopic properties were identical to those reported above.
( \pm )-2-Methyl-1,4,7-tris[(4-methylphenyl)sulfonyl]-1,4,7triazacyclononane $17 \mathbf{a}$.

(a) Method C (sodium hydride in DMF) (Table 1, entry 3). To a stirred solution of the 4-methyl- $N$-(1-methyl-2-\{[(4-methylphenyl)sulfonyl]amino\}ethyl)benzenesulfonamide 16a (300 mg, $0.79 \mathrm{mmol})$ and 2-[[(4-methylphenyl)sulfonyl] (3-\{[(4-methylphenyl)sulfonyl]oxy \}propyl)amino]ethyl-4-methylbenzenesulfonate $5(443 \mathrm{mg}, 0.78 \mathrm{mmol})$ in DMF $\left(7 \mathrm{~cm}^{3}\right)$ at $60^{\circ} \mathrm{C}$ was added a suspension of hexane washed sodium hydride $(60 \%$ in oil, $65 \mathrm{mg}$, $1.63 \mathrm{mmol})$ in DMF $\left(2 \mathrm{~cm}^{3}\right)$ over a $3 \mathrm{~h}$ period. The reaction mixture was then brought to $80^{\circ} \mathrm{C}$ and maintained at that temperature for a further 2 days. At the completion of this period the volatiles were removed $(12 \mathrm{~mm} \mathrm{Hg})$ and the residue was dissolved in ethyl acetate $\left(15 \mathrm{~cm}^{3}\right)$. This solution was washed with water $\left(2 \times 15 \mathrm{~cm}^{3}\right)$, dried $\left(\mathrm{Na}_{2} \mathrm{SO}_{4}\right)$, filtered and evaporated to afford an oil. Purification by column chromatography using ethyl aceate-hexane $(2: 3)$ as the eluant afforded an oil that precipated the title macrocycle from hot ethanol as a white solid ( $47 \mathrm{mg}, 0.08 \mathrm{mmol}, 10 \%)$. The physical and spectroscopic data were identical to those reported below using method $\mathrm{E}$.

(b) Method E (lithium hydride in DMF) (Table 1, entry 8). To a stirred suspension of lithium hydride $(17 \mathrm{mg}, 2.2 \mathrm{mmol})$ in anhydrous DMF $\left(10 \mathrm{~cm}^{3}\right)$ at $0{ }^{\circ} \mathrm{C}$ was added a solution of 4methyl- $N$-(1-methyl-2-\{[(4-methylphenyl)sulfonyl]amino\}ethyl)benzenesulfonamide 16a $(820 \mathrm{mg}, 2.15 \mathrm{mmol})$ in DMF $\left(2 \mathrm{~cm}^{3}\right)$ over a $20 \mathrm{~min}$ period. The resulting mixture was warmed to room temperature, whereupon, a solution of 2-[[(4-methylphenyl)sulfonyl](3 - \{[(4 - methylphenyl)sulfonyl]oxy $\}$ propyl)amino]ethyl4-methylbenzenesulfonate $5(1.217 \mathrm{~g}, 2.1 \mathrm{mmol})$ in DMF $\left(2 \mathrm{~cm}^{3}\right)$ was added dropwise over $1 \mathrm{~h}$. The cloudy suspension was then heated to $80{ }^{\circ} \mathrm{C}$ and the final aliquot of lithium hydride $(17 \mathrm{mg}$, $2.2 \mathrm{mmol}$ ) was added to the now homogeneous solution. The reaction was stirred at $80{ }^{\circ} \mathrm{C}$ for 5 days and at the completion of this period was cooled to room temperature and quenched by addition of water $\left(15 \mathrm{~cm}^{3}\right)$. The volatiles were removed under reduced pressure $(0.5 \mathrm{~mm} \mathrm{Hg})$ and the residue was dissolved in dichloromethane $\left(25 \mathrm{~cm}^{3}\right)$. The organic layer was washed with water $\left(15 \mathrm{~cm}^{3}\right)$ then brine $\left(15 \mathrm{~cm}^{3}\right)$ and dried $\left(\mathrm{Na}_{2} \mathrm{SO}_{4}\right)$, filtered and evaporated. The resulting yellow oil was dissolved in ethanol $\left(8 \mathrm{~cm}^{3}\right)$ and heated to reflux for $2 \mathrm{~h}$. Slow crystallisation from this solution over several days gave the title macrocycle as a white microcrystalline solid (784 mg, $1.3 \mathrm{mmol}, 60 \%$ ). An analytically pure sample was obtained by recrystallisation from $\mathrm{CHCl}_{3}-\mathrm{MeOH}$ which gave microcrystalline white pellets; $\mathrm{mp} 203-205^{\circ} \mathrm{C}$ (lit. ${ }^{18 d}$ 193-194 ${ }^{\circ} \mathrm{C}$ ). Found: C, 55.3; H, 5.8; N, 6.8; S, 15.6\%; $\mathrm{MH}^{+}$ 606.1766. $\mathrm{C}_{28} \mathrm{H}_{35} \mathrm{~N}_{3} \mathrm{O}_{6} \mathrm{~S}_{3}$ requires: $\mathrm{C}, 55.5 ; \mathrm{H}, 5.8 ; \mathrm{N}, 6.9 ; \mathrm{S}, 15.9 \%$; $\mathrm{MH}^{+}$606.1766. $v_{\max }\left(\mathrm{KBr}, \mathrm{cm}^{-1}\right) 3029\left(\mathrm{w}, \mathrm{C}_{6} \mathrm{H}_{4}\right), 2928(\mathrm{w}, \mathrm{CH})$, $1339\left(\mathrm{~s}, \mathrm{SO}_{2} \mathrm{NH}\right), 1158\left(\mathrm{~s}, \mathrm{SO}_{2} \mathrm{NH}\right), 816\left(\mathrm{w} \mathrm{C}_{6} \mathrm{H}_{4}\right) ; \delta_{\mathrm{H}}(400 \mathrm{MHz}$, $\left.\mathrm{CDCl}_{3}\right) 0.78\left(\mathrm{~d}, J 5.2 \mathrm{~Hz}, 3 \mathrm{H}, \mathrm{CH}_{3} \mathrm{CH}\right), 2.43\left(\mathrm{~s}, 9 \mathrm{H}, 3 \times \mathrm{C}_{6} \mathrm{H}_{4} \mathrm{CH}_{3}\right)$, 3.09-3.19 (m, 3H, $\left.\mathrm{CH}_{2}\right), 3.31-3.39\left(\mathrm{~m}, 3 \mathrm{H}, \mathrm{CH}_{2}\right), 3.49-3.53(\mathrm{~m}$, $\left.1 \mathrm{H}, \mathrm{CH}_{2}\right), 3.62-3.68\left(\mathrm{~m}, 3 \mathrm{H}, \mathrm{CH}_{2}\right), 4.40-4.53\left(\mathrm{~m}, 1 \mathrm{H}, \mathrm{CH}_{2} \mathrm{CH}\right)$, 7.29-7.37 (m, 6H, $\left.\mathrm{C}_{6} H_{4} \mathrm{CH}_{3}\right), 7.62\left(\mathrm{~d}, J 8.4,2 \mathrm{H}, \mathrm{C}_{6} H_{4} \mathrm{CH}_{3}\right)$, $7.75\left(\mathrm{~d}, J 8.0,2 \mathrm{H}, \mathrm{C}_{6} H_{4} \mathrm{CH}_{3}\right), 7.78\left(\mathrm{~d}, J 8.4,2 \mathrm{H}, \mathrm{C}_{6} H_{4} \mathrm{CH}_{3}\right)$; $\delta_{\mathrm{C}}\left(100 \mathrm{MHz}, \mathrm{CDCl}_{3}\right) 14.6\left(\mathrm{CH}_{3} \mathrm{CH}\right), 21.7\left(3 \times \mathrm{C}_{6} \mathrm{H}_{4} \mathrm{CH}_{3}\right), 45.8$ $\left(\mathrm{NCH}_{2}\right), 50.8\left(\mathrm{NCH}_{2}\right), 53.3\left(\mathrm{NCH}_{2}\right), 54.0\left(\mathrm{NCH}_{2}\right), 54.3\left(\mathrm{NCH}_{2}\right)$, $55.3(\mathrm{NCH}), 127.5\left(2 \times C_{6} \mathrm{H}_{4} \mathrm{CH}_{3}\right), 127.6\left(2 \times \mathrm{C}_{6} \mathrm{H}_{4} \mathrm{CH}_{3}\right), 127.8$ $\left(2 \times \mathrm{C}_{6} \mathrm{H}_{4} \mathrm{CH}_{3}\right), 130.0\left(4 \times \mathrm{C}_{6} \mathrm{H}_{4} \mathrm{CH}_{3}\right), 130.1\left(2 \times \mathrm{C}_{6} \mathrm{H}_{4} \mathrm{CH}_{3}\right)$, 134.5, 135.2, $136.8($ all $\operatorname{ArC}), 143.8(2 \times \operatorname{ArC}), 144.3(\operatorname{ArC})$. 


\section{1,4,7-Tris[(4-methylphenyl)sulfonyl]-1,4,7-triazacyclononane} $17 \mathrm{~b}$.

Method E (lithium hydride in DMF) (Table 1, entry 7). To a stirred suspension of lithium hydride (33 $\mathrm{mg}, 4.18 \mathrm{mmol})$ in anhydrous DMF $\left(15 \mathrm{~cm}^{3}\right)$ was added 4-methyl- $N$-(2$\{[(4-m e t h y l p h e n y l)$ sulfonyl $]$ amino $\}$ ethyl)benzenesulfonamide $\mathbf{1 6 b}$ (731 mg, $1.98 \mathrm{mmol}$ ) under a nitrogen atmosphere. The resulting mixture was heated to $70{ }^{\circ} \mathrm{C}$ for $2 \mathrm{~h}$, whereupon, it was cooled to $50{ }^{\circ} \mathrm{C}$. A solution of 2-[[(4-methylphenyl)sulfonyl](3- $\{[(4-m e t h y l-$ phenyl)sulfonyl]oxy $\}$ propyl)amino]ethyl-4-methylbenzenesulfonate $5(1.24 \mathrm{~g}, 2.18 \mathrm{mmol})$ in DMF $\left(3.6 \mathrm{~cm}^{3}\right)$ was added dropwise over a $2.5 \mathrm{~h}$ period. The reaction mixture was maintained at $50{ }^{\circ} \mathrm{C}$ for 5 days, whereupon, it was cooled to room temperature. Water $\left(5 \mathrm{~cm}^{3}\right)$ was added and the volatiles were removed in vacuo $(0.5 \mathrm{~mm}$ $\mathrm{Hg}$ ). The resulting residue was dissolved in dichloromethane $\left(25 \mathrm{~cm}^{3}\right)$. and washed with water $\left(15 \mathrm{~cm}^{3}\right)$ then brine $\left(15 \mathrm{~cm}^{3}\right)$ and dried $\left(\mathrm{Na}_{2} \mathrm{SO}_{4}\right)$, filtered and evaporated. The resulting oil was suspended in ethanol $\left(15 \mathrm{~cm}^{3}\right)$ and heated to reflux for $2 \mathrm{~h}$ under a nitrogen atmosphere which afforded the title compound $\mathbf{1 7} \mathbf{b}$ as a white solid (1.07 g, $1.8 \mathrm{mmol}, 91 \%)$. An analytical sample was obtained by recrystallisation from $\mathrm{CHCl}_{3}-\mathrm{MeOH}$ which gave fine white needles; $\mathrm{mp} 222-223{ }^{\circ} \mathrm{C}$ (lit. ${ }^{24} 218-220^{\circ} \mathrm{C}$ ). Found: C, 54.5; $\mathrm{H}, 5.6, \mathrm{~N}, 7.0 ; \mathrm{S}, 16.0 \%$; $\mathrm{MH}^{+} 592.1609 . \mathrm{C}_{27} \mathrm{H}_{33} \mathrm{~N}_{3} \mathrm{O}_{6} \mathrm{~S}_{3}$ requires: C, 54.8; H, 5.6; N, 7.1; S, 16.3\%; $\mathrm{MH}^{+} 592.1609 . v_{\max }\left(\mathrm{KBr}, \mathrm{cm}^{-1}\right)$ 2927 (w, CH), 1336 (s, SO $\mathrm{SH}_{2}$ ), 1322 (m), 1161 (s, SO $\left.\mathrm{SO}_{2} \mathrm{NH}\right), 817$ $(\mathrm{w}, \mathrm{C} 6 \mathrm{H} 4) ; \delta_{\mathrm{H}}\left(400 \mathrm{MHz}, \mathrm{CDCl}_{3}\right) 2.41\left(\mathrm{~s}, 9 \mathrm{H}, 3 \times \mathrm{C}_{6} \mathrm{H}_{4} \mathrm{CH}_{3}\right), 3.46$ $\left(\mathrm{s}, 12 \mathrm{H}, 6 \times \mathrm{NCH}_{2}\right), 7.31\left(\mathrm{~d}, J 8.0 \mathrm{~Hz}, 6 \mathrm{H}, \mathrm{C}_{6} H_{4} \mathrm{CH}_{3}\right), 7.69$ (d, $J$ $\left.8.0,6 \mathrm{H}, \mathrm{C}_{6} \mathrm{H}_{4} \mathrm{CH}_{3}\right) ; \delta_{\mathrm{C}}\left(100 \mathrm{MHz}, \mathrm{CDCl}_{3}\right), 21.7\left(3 \times \mathrm{C}_{6} \mathrm{H}_{4} \mathrm{CH}_{3}\right)$, $52.0\left(6 \times \mathrm{NCH}_{2}\right), 127.6\left(6 \times \mathrm{C}_{6} \mathrm{H}_{4} \mathrm{CH}_{3}\right), 130.0\left(6 \times \mathrm{C}_{6} \mathrm{H}_{4} \mathrm{CH}_{3}\right)$, $134.8(3 \times \operatorname{ArC}), 144.0(3 \times \operatorname{ArC})$.

(7a $R, 11 \mathrm{a} R)$-1,4,7-Tris[(4-methylphenyl)sulfonyl]dodecahydro$1 H$-1,4,7-benzotriazonine 3 .

Method E (lithium hydride in DMF) (Table 1, entry 10). The title compound $(1 R, 2 R)-3$ was prepared in a similar manner to 17b via method $\mathrm{E}$ using $(1 R, 2 R)-4-$ methyl- $N-(2-\{[(4-$ methylphenyl)sulfonyl]amino $\}$ cyclohexyl)benzenesulfonamide 4 (2.70 g, $6.4 \mathrm{mmol})$ and 2-[[(4-methylphenyl)sulfonyl] (3-\{[(4methylphenyl)sulfonyl] oxy $\}$ propyl)amino]ethyl-4-methylbenzenesulfonate 5 (4.00 g, $7 \mathrm{mmol}$ ) which afforded the title macrocycle as a white solid (2.81 g, $0.25 \mathrm{mmol}, 68 \%$ ); mp $301-302{ }^{\circ} \mathrm{C}$ (lit. ${ }^{19 c} 294$ $295^{\circ} \mathrm{C}$ ); Found: C, 57.7; H, 6.1; N, 6.5; S, 14.9\%; $\mathrm{MH}^{+} 646.2086$. $\mathrm{C}_{31} \mathrm{H}_{39} \mathrm{O}_{6} \mathrm{~S}_{3} \mathrm{~N} 3$ requires: $\mathrm{C}, 57.7 ; \mathrm{H}, 6.1 ; \mathrm{N}, 6.5 ; \mathrm{S}, 14.9 \% ; \mathrm{MH}^{+}$ 646.2079; $[\alpha]_{\mathrm{D}}=-63.4\left(c=1, \mathrm{CHCl}_{3}\right)\left[\right.$ lit. $^{19 c}[\alpha]_{\mathrm{D}}=-53.9(c=1$, $\left.\left.\mathrm{CH}_{2} \mathrm{Cl}_{2}\right)\right] . v_{\max }\left(\mathrm{KBr}, \mathrm{cm}^{-1}\right) 3065\left(\mathrm{w}, \mathrm{C}_{6} \mathrm{H}_{4}\right), 2928(\mathrm{~m}, \mathrm{CH}), 2865(\mathrm{~m}$, $\mathrm{CH}), 1326\left(\mathrm{~s}, \mathrm{SO}_{2} \mathrm{NH}\right), 1153\left(\mathrm{~s}, \mathrm{SO}_{2} \mathrm{NH}\right) ; \delta_{\mathrm{H}}\left(400 \mathrm{MHz}, \mathrm{CDCl}_{3}\right)$ $1.11\left(\mathrm{~m}, 2 \mathrm{H}, \mathrm{CH}_{2}\right), 1.26\left(\mathrm{~m}, 2 \mathrm{H}, \mathrm{CH}_{2}\right), 1.56\left(\mathrm{~m}, 2 \mathrm{H}, \mathrm{CH}_{2}\right), 1.76(\mathrm{~m}$, $\left.1 \mathrm{H}, \mathrm{CH}_{2}\right), 2.16\left(\mathrm{~m}, 1 \mathrm{H}, \mathrm{CH}_{2}\right), 2.35\left(\mathrm{~s}, 3 \mathrm{H}, \mathrm{C}_{6} \mathrm{H}_{4} \mathrm{CH}_{3}\right), 2.41(\mathrm{~s}, 6 \mathrm{H}$, $\left.\mathrm{C}_{6} \mathrm{H}_{4} \mathrm{CH}_{3}\right), 2.59\left(\mathrm{~m}, 1 \mathrm{H}, \mathrm{CH}_{2} \mathrm{NTs}\right), 3.11\left(\mathrm{~m}, 1 \mathrm{H}, \mathrm{CH}_{2} \mathrm{NTs}\right), 3.27$ (m, $\left.3 \mathrm{H}, \mathrm{CH}_{2} \mathrm{NTs}\right), 3.49$ (m, 3H, CH $\left.\mathrm{H}_{2} \mathrm{NTs}\right), 3.75$ (m, 1H, CHNTs), $4.89(\mathrm{~m}, 1 \mathrm{H}, \mathrm{CHNTs}), 7.29\left(\mathrm{~m}, 6 \mathrm{H}, \mathrm{C}_{6} H_{4} \mathrm{CH}_{3}\right), 7.61$ (d, J $8.3 \mathrm{~Hz}$, $2 \mathrm{H}, \mathrm{C}_{6} \mathrm{H}_{4} \mathrm{CH}_{3}$ ), $7.76\left(\mathrm{~m}, 2 \mathrm{H}, \mathrm{C}_{6} \mathrm{H}_{4} \mathrm{CH}_{3}\right), 8.00\left(\mathrm{~m}, 2 \mathrm{H}, \mathrm{C}_{6} \mathrm{H}_{4} \mathrm{CH}_{3}\right.$ ); $\delta_{\mathrm{C}}\left(100 \mathrm{MHz}, \mathrm{CDCl}_{3}\right) 21.7\left(3 \times \mathrm{C}_{6} \mathrm{H}_{4} \mathrm{CH}_{3}\right), 24.7\left(\mathrm{CH}_{2}\right), 26.1$ $\left(\mathrm{CH}_{2}\right), 29.0\left(\mathrm{CH}_{2}\right), 30.3\left(\mathrm{CH}_{2}\right), 47.1\left(\mathrm{CH}_{2} \mathrm{NTs}\right), 52.4\left(\mathrm{CH}_{2} \mathrm{NTs}\right)$, $55.0\left(\mathrm{CH}_{2} \mathrm{NTs}\right), 55.8\left(\mathrm{CH}_{2} \mathrm{NTs}\right), 60.2$ (CHNTs), 68.2 (CHNTs), $127.3(2 \times \mathrm{ArCH}), 127.9(2 \times \mathrm{ArCH}), 128.7(2 \times \mathrm{ArCH}), 129.7$ $(2 \times \mathrm{ArCH}), 129.9(4 \times \mathrm{ArCH}), 130.1(2 \times \mathrm{ArC}), 135.1(\mathrm{ArC})$, 137.5 (ArC), $143.6(\operatorname{ArC}), 144.2(\operatorname{ArC})$.
( \pm )-1,7-Bis[(4-methylphenyl)sulfonyl]-4-[(4-nitrophenyl)sulfonyl]dodecahydro-1 $\boldsymbol{H}$-1,4,7-benzotriazonine 19.

Method E (lithium hydride in DMF) (Table 1, entry 11). The title compound $\mathbf{1 9}$ was prepared in a similar manner to 17b via method $\mathrm{E}$ using ( \pm )-4-methyl- $N$-(2- $\{[$ (4-methylphenyl)sulfonyl]amino\}cyclohexyl)benzenesulfonamide 4 (306 $\mathrm{mg}$, $0.72 \mathrm{mmol})$ and 2-[[(4-nitrophenyl)sulfonyl](2-\{[(4-nitrophenyl)sulfonyl]oxy\}ethyl)amino]ethyl 3-nitrobenzenesulfonate $\mathbf{1 8}$ (521 mg, $0.79 \mathrm{mmol}$ ) which afforded the title compound $\mathbf{1 9}$ as a white solid (279 $\mathrm{mg}, 0.41 \mathrm{mmol}, 57 \%)$. An analytical sample was obtained by column chromatography using alumina (grade III) using dichloromethane as the eluant which gave a white microcrystalline solid; mp 262-264 ${ }^{\circ} \mathrm{C}$. Found: C, 53.5; H, 5.4; $\mathrm{N}, 7.9 \% ; \mathrm{MH}^{+} 677.1767$. Calculated for $\mathrm{C}_{30} \mathrm{H}_{36} \mathrm{~N}_{4} \mathrm{O}_{8} \mathrm{~S}_{3}$ : C, 53.2; $\mathrm{H}, 5.4 ; \mathrm{N}, 8.3 \% \mathrm{MH}^{+}$677.1773. $v_{\max }\left(\mathrm{KBr}, \mathrm{cm}^{-1}\right) 2930(\mathrm{w}, \mathrm{CH})$, 1599 (w, Ar), 1531 (s, $\mathrm{ArNO}_{2}$ ), 1352 (s, $\mathrm{ArNO}_{2}$ ), 1331 (s, $\left.\mathrm{SO}_{2} \mathrm{NH}\right)$, $1158\left(\mathrm{~s}, \mathrm{SO}_{2} \mathrm{NH}\right) ; \delta_{\mathrm{H}}\left(400 \mathrm{MHz}, \mathrm{CDCl}_{3}\right) 1.09-1.19\left(\mathrm{~m}, 2 \mathrm{H}, \mathrm{CH}_{2}\right)$, $1.21-1.42\left(\mathrm{~m}, 3 \mathrm{H}, \mathrm{CH}_{2}\right), 1.52-1.56\left(\mathrm{~m}, 1 \mathrm{H}, \mathrm{CH}_{2}\right), 1.72-1.80$ $\left(\mathrm{m}, 1 \mathrm{H}, \mathrm{CH}_{2}\right), 2.04-2.14\left(\mathrm{~m}, 1 \mathrm{H}, \mathrm{CH}_{2}\right), 2.39\left(\mathrm{~s}, 3 \mathrm{H}, \mathrm{C}_{6} \mathrm{H}_{4} \mathrm{CH}_{3}\right)$, $2.42\left(\mathrm{~s}, 3 \mathrm{H}, \mathrm{C}_{6} \mathrm{H}_{4} \mathrm{CH}_{3}\right), 2.73-2.85$ (m, $\left.1 \mathrm{H}, \mathrm{CH}_{2} \mathrm{NTs}\right), 3.18-3.35$ (m, $\left.4 \mathrm{H}, \mathrm{CH}_{2} \mathrm{NTs}\right), 3.44-3.59\left(\mathrm{~m}, 3 \mathrm{H}, \mathrm{CH}_{2} \mathrm{NTs} 3.72-3.75(\mathrm{~m}\right.$, $1 \mathrm{H}, \mathrm{C} H \mathrm{NTs}), 4.79-4.80(\mathrm{~m}, 1 \mathrm{H}, \mathrm{CHNTs}), 7.23-7.36(\mathrm{~m}, 4 \mathrm{H}$, $\left.\mathrm{C}_{6} H_{4} \mathrm{SO}_{2}\right), 7.23-7.36\left(\mathrm{~m}, 4 \mathrm{H}, \mathrm{C}_{6} H_{4} \mathrm{CH}_{3}\right), 7.75(\mathrm{~d}, J 6.0 \mathrm{~Hz}$, $\left.2 \mathrm{H}, \mathrm{C}_{6} H_{4} \mathrm{SO}_{2}\right), 7.92-8.01\left(\mathrm{~m}, 2 \mathrm{H}, \mathrm{C}_{6} H_{4} \mathrm{SO}_{2}\right) 7.91(\mathrm{~d}, J 8.4,2 \mathrm{H}$, $\left.\mathrm{C}_{6} H_{4} \mathrm{SO}_{2}\right), 8.29\left(\mathrm{~d}, J 8.4,2 \mathrm{H}, \mathrm{C}_{6} H_{4} \mathrm{NO}_{2}\right) ; \delta_{\mathrm{C}}\left(100 \mathrm{MHz}, \mathrm{CDCl}_{3}\right)$ $21.6\left(2 \times \mathrm{C}_{6} \mathrm{H}_{4} \mathrm{CH}_{3}\right), 24.6\left(\mathrm{CH}_{2}\right) 26.0\left(\mathrm{CH}_{2}\right), 28.9\left(\mathrm{CH}_{2}\right), 30.2$ $\left(\mathrm{CH}_{2}\right), 46.9\left(\mathrm{NCH}_{2}\right), 52.5\left(\mathrm{NCH}_{2}\right), 55.4\left(\mathrm{NCH}_{2}\right), 55.7\left(\mathrm{NCH}_{2}\right)$, $60.3(\mathrm{NCH}), 68.2(\mathrm{NCH}), 124.7\left(4 \times C_{6} \mathrm{H}_{4} \mathrm{SO}_{2}\right), 127.7\left(C_{6} \mathrm{H}_{4} \mathrm{SO}_{2}\right)$, $128.5\left(C_{6} \mathrm{H}_{4} \mathrm{SO}_{2}\right) 128.6\left(4 \times C_{6} \mathrm{H}_{4} \mathrm{SO}_{2}\right), 129.7\left(C_{6} \mathrm{H}_{4} \mathrm{SO}_{2}\right), 129.9$ $\left(C_{6} \mathrm{H}_{4} \mathrm{SO}_{2}\right), 137.2(\mathrm{ArC}), 138.2(\mathrm{ArC}), 143.4(2 \times \mathrm{ArC}), 143.8$ $(\operatorname{ArC}), 150.4(\operatorname{ArC})$.

\section{Deprotection and $N$-methylation}

(7a $R, 11 \mathrm{a} R$ )-Dodecahydro-1 $H$-1,4,7-benzotriazonine trihydrochloride 20. To a solution of 1,4,7-tris[(4-methylphenyl)sulfonyl]dodecahydro-1 $H$-1,4,7-benzotriazonine $(R, R)-3(1.00 \mathrm{~g}$, $1.5 \mathrm{mmol})$ in THF $\left(25 \mathrm{~cm}^{3}\right)$ and $\mathrm{EtOH}\left(4.8 \mathrm{~cm}^{3}, 84 \mathrm{mmol}\right)$ was condensed dry $\mathrm{NH}_{3}\left(200 \mathrm{~cm}^{3}\right)$ at $-78{ }^{\circ} \mathrm{C}$. To this solution was added lithium metal (542 $\mathrm{mg}, 77 \mathrm{mmol}$ ) in small portions to give an intense blue colour. The reaction mixture was allowed to warm to room temperature overnight. Water was added $\left(10 \mathrm{~cm}^{3}\right)$ and the solution was acidified $(\mathrm{pH} 1)$ with conc. $\mathrm{HCl}\left(1 \mathrm{~cm}^{3}\right)$. The aqueous solution was extracted with dichloromethane $(\times 2$, $\left.10 \mathrm{~cm}^{3}\right)$. The aqueous phase was made basic $(\mathrm{pH} \mathrm{14})$ by addition of solid $\mathrm{NaOH}$ ( $c a .500 \mathrm{mg}$ ). The basic solution was extracted with dichloromethane $\left(\times 4,10 \mathrm{~cm}^{3}\right)$ and the combined organic phases were dried $\left(\mathrm{Na}_{2} \mathrm{SO}_{4}\right)$, filtered and evaporated to give a crude dark yellow oil $(310 \mathrm{mg})$. The yellow oil was dissolved in methanol $\left(2 \mathrm{~cm}^{3}\right)$ and conc. $\mathrm{HCl}\left(0.08 \mathrm{~cm}^{3}\right)$ was added dropwise at room temperature with rapid stirring. To this solution was added diethyl ether $\left(8 \mathrm{~cm}^{3}\right)$ and the white precipitate that formed was removed by filtration and dried under reduced pressure to give the crude hydrochloride salt (297 mg, $1.1 \mathrm{mmol}, 73 \%)$; mp 176-178 ${ }^{\circ} \mathrm{C}$ (lit. ${ }^{19 c} 240{ }^{\circ} \mathrm{C}$ (decomp.). Found: C, 40.6; H, 8.6; $\mathrm{N}, 13.1 \%$; $(\mathrm{MH}-3 \mathrm{HCl})^{+} 184.1815 . \mathrm{C}_{10} \mathrm{H}_{21} \mathrm{~N}_{3} \cdot \mathrm{MeOH}$ requires: $\mathrm{C}, 40.7 ; \mathrm{H}, 8.7 ; \mathrm{N}, 12.9 \% ;(\mathrm{MH}-3 \mathrm{HCl})^{+} 184.1813 ;[\alpha]_{\mathrm{D}}-122$ $\left(c=0.135, \mathrm{H}_{2} \mathrm{O}\right)\left(\right.$ (lit. $^{19 \mathrm{c}}[\alpha]_{\mathrm{D}}=-55.6\left(c=0.4, \mathrm{H}_{2} \mathrm{O}\right) . v_{\max }$ $\left(\mathrm{KBr}, \mathrm{cm}^{-1}\right) 3419$ (w, NH); 2943 (s, CH), 2862 (s, CH), 2778 
$(\mathrm{s}, \mathrm{CH}) ; \delta_{\mathrm{H}}\left(400 \mathrm{MHz}, \mathrm{D}_{2} \mathrm{O}\right) 1.31\left(\mathrm{~m}, 2 \mathrm{H}, \mathrm{CH}_{2}\right), 1.50\left(\mathrm{~m}, 2 \mathrm{H}, \mathrm{CH}_{2}\right)$, $1.82\left(\mathrm{~m}, 2 \mathrm{H}, \mathrm{CH}_{2}\right), 2.10\left(\mathrm{~m}, 2 \mathrm{H}, \mathrm{CH}_{2}\right), 3.13\left(\mathrm{~m}, 2 \mathrm{H}, \mathrm{NHCH}_{2}\right), 3.31$ $\left(\mathrm{m}, 6 \mathrm{H}, \mathrm{NHCH}_{2}\right), 3.41(\mathrm{~m}, 2 \mathrm{H}, \mathrm{NHCH}) ; \delta_{\mathrm{C}}\left(100 \mathrm{MHz}, \mathrm{CD}_{3} \mathrm{OD}\right)$ $24.3\left(2 \times \mathrm{CH}_{2}\right), 29.7\left(2 \times \mathrm{CH}_{2}\right), 39.7\left(2 \times \mathrm{NHCH}_{2}\right), 43.2(2 \times$ $\left.\mathrm{NHCH}_{2}\right), 57.7(2 \times \mathrm{NHCH})$.

(7a $R, 11 \mathrm{a} R)$ - 1,4,7 - Trimethyldodecahydro - $1 H$ - 1,4,7 - benzotri azonine 1. $(7 \mathrm{a} R, 11 \mathrm{a} R)$-Dodecahydro- $1 H-1,4,7$-benzotriazonine trihydrochloride $(R, R)$-20 (305 $\mathrm{mg}, 1.04 \mathrm{mmol})$ was dissolved in water $\left(20 \mathrm{~cm}^{3}\right)$ and the solution was made basic ( $\mathrm{pH} \mathrm{14)}$ by the addition of solid $\mathrm{NaOH}(c a .250 \mathrm{mg})$. The basic solution was extracted with dichloromethane $\left(\times 4,10 \mathrm{~cm}^{3}\right)$ and the combined organic phases were dried $\left(\mathrm{Na}_{2} \mathrm{SO}_{4}\right)$, filtered and evaporated to give a pale yellow oil. To this oil was added formaldehyde (38\%, $\left.0.8 \mathrm{~cm}^{3}\right)$ and formic acid $\left(90 \%, 0.9 \mathrm{~cm}^{3}\right)$ and the solution was heated to reflux (bath temp. $90^{\circ} \mathrm{C}$ ) under a nitrogen atmosphere for $20 \mathrm{~h}$. After cooling to room temperature the reaction was acidified (pH 1) with conc. $\mathrm{HCl}\left(1 \mathrm{~cm}^{3}\right)$ and the volatiles were removed under reduced pressure. The aqueous solution was extracted with dichloromethane $\left(\times 2,10 \mathrm{~cm}^{3}\right)$. The aqueous phase was made basic (pH 14) by addition of solid $\mathrm{NaOH}$ ( $c a .250 \mathrm{mg}$ ). The basic solution was extracted with dichloromethane $\left(\times 4,10 \mathrm{~cm}^{3}\right)$, and the combined organic phases were dried $\left(\mathrm{Na}_{2} \mathrm{SO}_{4}\right)$, filtered and evaporated to give a pale yellow oil (185 $\mathrm{mg}, 0.82 \mathrm{mmol}, 79 \%)$. Found: $\mathrm{MH}^{+}$226.2280. Calculated for $\mathrm{C}_{13} \mathrm{H}_{27} \mathrm{~N}_{3} \mathrm{MH}^{+}$: 226.2283; $[a]_{\mathrm{D}}-48.8\left(c=0.5, \mathrm{CHCl}_{3}\right), v_{\max }$ (liq. film, $\left.\mathrm{cm}^{-1}\right) 2933(\mathrm{~m}, \mathrm{CH})$, $2857(\mathrm{~m}, \mathrm{CH}), 2791(\mathrm{~m}, \mathrm{CH}), 1666(\mathrm{~s}), 1451(\mathrm{~s}, \mathrm{CH}), 732\left(\mathrm{~s}, \mathrm{CH}_{2}\right)$; $\delta_{\mathrm{H}}\left(400 \mathrm{MHz}, \mathrm{CDCl}_{3}\right) 1.05\left(\mathrm{~m}, 4 \mathrm{H}, \mathrm{CH}_{2}\right), 1.63\left(\mathrm{~m}, 2 \mathrm{H}, \mathrm{CH}_{2}\right), 1.73$ $\left(\mathrm{m}, 2 \mathrm{H}, \mathrm{CH}_{2}\right), 2.29\left(\mathrm{~s}, 9 \mathrm{H}, \mathrm{NCH}_{3}\right), 2.48\left(\mathrm{~m}, 6 \mathrm{H}, \mathrm{NCH}_{2}\right), 2.60$ (m, $\left.2 \mathrm{H}, \mathrm{NCH}_{2}\right) 2.95(\mathrm{~m}, 2 \mathrm{H}, \mathrm{NCH}) ; \delta_{\mathrm{C}}\left(100 \mathrm{MHz}, \mathrm{CDCl}_{3}\right) 25.2(2 \times$ $\left.\mathrm{CH}_{2}\right), 27.0\left(2 \times \mathrm{CH}_{2}\right), 40.2\left(2 \times \mathrm{NCH}_{3}\right), 46.8\left(\mathrm{NCH}_{3}\right), 54.4(2 \times$ $\left.\mathrm{NCH}_{2}\right), 54.8\left(2 \times \mathrm{NCH}_{2}\right), 63.6(2 \times \mathrm{NCH})$.

\section{Copper(II) complex formation}

To a solution of copper(II) chloride (162 mg, $1.2 \mathrm{mmol})$ in anhydrous acetonitrile $\left(20 \mathrm{~cm}^{3}\right)$ under a nitrogen atmosphere was added a solution of $(7 \mathrm{a} R, 11 \mathrm{a} R)$-1,4,7-trimethyldodecahydro- $1 H$ 1,4,7-benzotriazonine $1(271 \mathrm{mg}, 1.2 \mathrm{mmol})$ in acetonitrile $\left(5 \mathrm{~cm}^{3}\right)$. The resulting green solution was stirred under nitrogen for $90 \mathrm{~min}$, whereupon, it was diluted with acetonitrile $\left(50 \mathrm{~cm}^{3}\right)$, and a solution of silver trifluoroacetate $(530 \mathrm{mg}, 2.4 \mathrm{mmol})$ in acetonitrile $\left(10 \mathrm{~cm}^{3}\right)$ was added. The now bright blue solution was stirred for $1 \mathrm{~h}$ giving a precipitate of silver(II) chloride. The reaction mixture was filtered through Celite and the solvent was evaporated to afford a blue solid. Recystallisation from acetone-diethyl ether gave the title compound as blue rhomboid crystals $(328 \mathrm{mg}$, $0.64 \mathrm{mmol}, 53 \%$ ) that were suitable for X-ray crystallography. Mp $211{ }^{\circ} \mathrm{C}$ (decomp.) Found: C, 39.4; H, 5.3; N, 8.1\%. Calculated for $\mathrm{C}_{17} \mathrm{H}_{27} \mathrm{CuF}_{6} \mathrm{~N}_{3} \mathrm{O}_{4}$ : C, 39.6; H, 5.3; N, 8.2\%. $v_{\max }\left(\mathrm{KBr}, \mathrm{cm}^{-1}\right) 2943$ (m, CH), 2859 (w, CH), 1705 (s), 1690 (s), 1422 (s), 1204 (s), 1180 (s), $1126(\mathrm{~s}), 723(\mathrm{~s}) ; \lambda_{\max }\left[\mathrm{CH}_{3} \mathrm{CN}, \mathrm{nm}(\varepsilon)\right] 284$ (4806), 548 (28), 652 (88).

\section{Aziridination of styrene 24}

A mixture of [ $N$-(4-tolylsulfonyl)imino]phenyliodinane ${ }^{42}(112 \mathrm{mg}$, $0.3 \mathrm{mmol})$ and complex $22(8 \mathrm{mg}, 15 \mu \mathrm{mol}, 5 \mathrm{~mol} \%)$ in acetonitrile $\left(2 \mathrm{~cm}^{3}\right)$ under a nitrogen atmosphere was stirred for $2 \mathrm{~h}$ until a homogeneous solution resulted. Styrene $\left(0.35 \mathrm{~cm}^{3}, 3 \mathrm{mmol}\right)$ was added and the reaction mixture was stirred for $72 \mathrm{~h}$. The resulting mixture was filtered through alumina using ethyl acetate as the eluant. Evaporation of the solvent and recrystallisation from diethyl ether-hexane at $-20{ }^{\circ} \mathrm{C}$ afforded 1-[(4-methylphenyl)sulfonyl]-2phenylaziridine 25 as an off-white solid (40 $\mathrm{mg}, 0.15 \mathrm{mmol}, 49 \%$ ) mp 86-88 ${ }^{\circ} \mathrm{C}$ (lit. ${ }^{17} 88-90^{\circ} \mathrm{C}$ ). Found: $\mathrm{MH}^{+}$274.0903. $\mathrm{C}_{15} \mathrm{H}_{15} \mathrm{NO}_{2} \mathrm{~S}$ requires: $\mathrm{MH}^{+}$274.0902. $v_{\max }\left(\mathrm{KBr}, \mathrm{cm}^{-1}\right) 3359$ (w, NHTs), 3042 (m, NH), 2977 (w, CH), 1316 (s, $\left.\mathrm{SO}_{2} \mathrm{NH}\right), 1154\left(\mathrm{~s}, \mathrm{SO}_{2} \mathrm{NH}\right) ; \delta_{\mathrm{H}}$ $\left(400 \mathrm{MHz}, \mathrm{CDCl}_{3}\right) 2.43(\mathrm{~d}, J 4.5 \mathrm{~Hz}, 1 \mathrm{H}, \mathrm{CHH}), 2,47(\mathrm{~s}, 3 \mathrm{H}$, $\left.\mathrm{C}_{6} \mathrm{H}_{4} \mathrm{CH}_{3}\right), 3.02(\mathrm{~d}, J 7.2,1 \mathrm{H}, \mathrm{CH} H), 3.82(\mathrm{dd}, J 7.2,4.5,1 \mathrm{H}$, $\mathrm{C} H \mathrm{Ph}), 7.25-7.38(\mathrm{~m}, 7 \mathrm{H}, \mathrm{ArCH}), 7.91\left(\mathrm{~d}, J 8.3,2 \mathrm{H}, \mathrm{C}_{6} H_{4}\right) ; \delta_{\mathrm{C}}$ $\left(100 \mathrm{MHz}, \mathrm{CDCl}_{3}\right) 21.9\left(\mathrm{C}_{6} \mathrm{H}_{4} \mathrm{CH}_{3}\right) 36.1\left(\mathrm{CH}_{2}\right), 41.3(\mathrm{CH}), 126.8$ $(2 \times \mathrm{ArCH}), 128.2(2 \times \mathrm{ArCH}), 128.5(\operatorname{ArC}), 128.8(\mathrm{ArCH}), 130.0$ $(2 \times \mathrm{ArCH}), 135.3(\mathrm{ArC}), 144.8(\operatorname{ArC})$. Chiral HPLC indicated that the two enatiomeric products were formed in a $1: 1$ ratio; $t_{\mathrm{R}}=$ $11.45 \mathrm{~min}$ and $13.98 \mathrm{~min}$

\section{Acknowledgements}

This work was funded under the Adventurous Chemistry award EP/C532309/1 which funded R. T. We also thank the EPSRC for a studentship (to G. S.). We are also grateful (K. R.-D.) for funding from the ERASMUS association and the region Rhône-Alpes. We also thank Raghu R. Morthala for recording a number of spectra.

\section{References}

1 For reviews, see: K. Wieghardt, Angew. Chem., Int. Ed. Engl., 1989, 28, 1153-1172; K. P. Wainwright, Coord. Chem. Rev., 1997, 166, 35-90.

2 For reviews, see: L. F. Lindoy, The Chemistry of Macrocyclic Ligand Complexes, Cambridge University Press, Cambridge, 1989; J. S. Bradshaw, K. E. Krakowiak and R. M. Izatt, The Chemistry of Heterocyclic Compounds: Aza-crown macrocycles, Wiley, New York, vol. 51, 1993.

3 For reviews of biomimetic manganese catalysts, see: R. Hage, Recl. Trav. Chim. Pays-Bas, 1996, 115, 385-395; K. Wieghardt, Angew. Chem., Int. Ed. Engl., 1989, 28, 1153-1172.

4 U. Bossek, M. Saher, T. Weyhermüller and K. Wieghardt, J. Chem. Soc., Chem. Commun., 1992, 1780-1782; K. Wieghardt, U. Bossek, B. Nuber, J. Weiss, J. Bonvoisin, M. Corbella, S. E. Vitols and J. J. Girerd, J. Am. Chem. Soc., 1988, 110, 7398-7411.

5 U. Bossek, T. Weyhermüller, K. Wieghardt, B. Nuber and J. Weiss, J. Am. Chem. Soc., 1990, 112, 6387-6388; K. Wieghardt, U. Bossek, Bonvoisin, P. Beauvillain, J. J. Girerd, B. Nuber, J. Weiss and J. Heinze, Angew. Chem., Int. Ed. Engl., 1986, 25, 1030-1031; K. Wieghardt, U. Bossek and W. Gebert, Angew. Chem., Int. Ed. Engl., 1983, 22, 328-329.

6 W. B. Tolman, Acc. Chem. Res., 1997, 97, 227-237; K. Wieghardt, U. Bossek, D. Ventur and J. Weiss, J. Chem. Soc., Chem. Commun., 1985, 347-349.

7 For a recent review of the oxidative applications of manganese 1,4,7triazacyclononane complexes, see: K. F. Sibbons, K. Shastri and M. Watkinson, Dalton Trans., 2006, 645-661.

8 M. Beller, A. Tafesh, R. W. Fischer and B. Scharbert, Ger. Pat., Ger. DE 195523 890, 1996 (Chem. Abstr., 1997, 126, 74725 g).

9 C. Bolm, D. Kadereit and M. Valacchi, Synlett, 1997, 687-688.

10 C. Bolm, N. Meyer, G. Raabe, T. Weyhermüller and E. Bothe, Chem. Commun., 2000, 2435-2436.

11 (a) G. Argouarch, C. L. Gibson, G. Stones and D. C. Sherrington, Tetrahedron Lett., 2002, 43, 3795-3798; (b) G. Stones, G. Argouarch, A. R. Kennedy, D. C. Sherrington and C. L. Gibson, Org. Biomol. Chem., 2003, 1, 2357-2363.

12 S. Niibayashi, H. Hayakawa, R.-H. Jin and H. Nagashima, Chem. Commun., 2007, 1855-1857.

13 K. P. McCue and J. R. Morrow, Inorg. Chem., 1999, 38, 6136-6142; E. L. Hegg, K. A. Deal, L. Kiessling and J. Burstyn, Inorg. Chem., 1997, 36, 1715-1718; A. O'Donoghue, S. Y. Pyun, M.-Y. Yang, J. R. Morrow and J. P. Richard, J. Am. Chem. Soc., 2006, 128, 1615-1621. 
14 C. Sissi, P. Rossi, F. Felluga, F. Fromaggio, M. Palumbo, P. Tecilla, C. Tonniolo and P. Scrimin, J. Am. Chem. Soc., 2001, 123, 3169-3170; A. Ehmann, D. Chafin, K.-M. Lee and J. J. Hayes, Nucleic Acids Res., 1998, 26, 2086-2091; E. L. Hegg and J. Burstyn, Inorg. Chem., 1996, 35, 7474-7481.

15 For a recent review of artificial metallonucleases, see: F. Mancin, P. Scrimin, P. Tecilla and U. Tonellato, Chem. Commun., 2005, 25402548.

16 E. L. Hegg and J. Burstyn, J. Am. Chem. Soc., 1995, 117, 70157016.

17 J. A. Halfen, J. K. Hallman, J. A. Schultz and J. P. Emerson, Organometallics, 1999, 18, 5435-5437.

18 (a) S. F. Mason and R. D. Peacock, Inorg. Chim. Acta, 1976, 19, 75-77; (b) A. F. Drake, R. Kuroda and S. F. Mason, J. Chem. Soc., Dalton Trans., 1979, 1095-1100; (c) M. Nonoyama, Transition Met. Chem., 1980, 5, 269-271; (d) P. G. Graham and D. C. Weatherburn, Aust. J. Chem., 1983, 36, 2349-2354; (e) J. P. L. Cox, A. S. Craig, I. M. Helps, K. J. Jankowski, D. Parker, M. A. W. Eaton, A. T. Millican, K. Millar, N. R. A. Beeley and B. A. Boyce, J. Chem. Soc., Perkin Trans. 1, 1990, 2567-2576; (f) J. H. Koek, E. W. M. J. Kohlen, S. W. Russell, L. von der Wolf, P. F. ter Steeg and J. C. Hellemons, Inorg. Chim. Acta, 1999, 295, 189-199; (g) L. J. Charbonnière, N. Wiebel and R. F. Ziessel, J. Org. Chem., 2002, 67, 3933-3936.

19 (a) M. Beller, A. Tafesh, R. W. Fischer and B. Scharbert, Ger. Pat., Ger. DE 19523 891, 1995 (Chem. Abstr., 1997, 126, 69346e); (b) S. W. Golding, T. W. Hambley, G. A. Lawrence, S. M. Luther, M. Maeder and P. Turner, J. Chem. Soc., Dalton Trans., 1999, 1875-1980; (c) S. Pulacchini, K. F. Sibbons, K. Shastri, M. Motevalli, M. Watkinson, H. Wan, A. Whiting and A. Lightfoot, Dalton Trans., 2003, 2043-2052; (d) S. Pulacchini, R. Nasser, K. F. Sibbons, M. Motevalli, G. E. Hawkes, R. T. Kroemer, E. S. Bento and M. Watkinson, Org. Biomol. Chem., 2003, 1, 4058-4063; (e) J. E. W. Scheuermann, E. S. Bento, G. E. Hawkes and M. Watkinson, Magn. Reson. Chem., 2005, 43, 321-325.

20 D. S. Kopac and D. G. Hall, J. Comb. Chem., 2002, 4, 251-254.

21 G. Argouarch, G. Stones, C. L. Gibson, A. R. Kennedy and D. C. Sherrington, Org. Biomol. Chem., 2003, 1, 4408-4417.

22 (a) B. M. Kim, S. M. So and H. J. Choi, Org. Lett., 2002, 4, 949-952; (b) J. E. Scheuermann, F. Ronketti, M. Motevalli, D. V. Griffiths and M. Watkinson, New J. Chem., 2002, 26, 1054-1059; (c) J. E. Scheuermann, K. F. Sibbons, D. M. Benoit, M. Motevalli and M. Watkinson, Org. Biomol. Chem., 2004, 2, 2664-2670.

23 L. Canali, E. Cowan, H. Deleuze, C. L. Gibson and D. C. Sherrington, J. Chem. Soc., Perkin Trans. 1, 2000, 2055-2066.

24 G. H. Searle and R. J. Geue, Aust. J. Chem., 1984, 37, 959-970.

25 W. L. Neumann, G. W. Franklin, K. R. Sample, K. W. Aston, R. H. Weiss and D. P. Riley, Tetrahedron Lett., 1997, 38, 779-82.
26 A. E. Martin, T. M. Ford and J. E. Bulkowski, J. Org. Chem., 1982, 47, 412-418.

27 J. E. Richman and T. J. Atkins, J. Am. Chem. Soc., 1974, 96, 2268-2270; T. J. Atkins, J. E. Richman and W. F. Oettle, Org. Synth., 1976, Coll. Vol. VI, 652-662; F. Chavez and A. D. Sherry, J. Org. Chem., 1989, 54, 2990-2992; S. Madison and D. J. Batal, World Pat., WO 94/00439, 1994; R. C. Hoye, J. E. Richman, G. A. Dantas, M. F. Lightbourne and L. S. Shinneman, J. Org. Chem., 2001, 66, 2722-2725.

28 J. F. Larrow, E. N. Jacobsen, Y. Gao, Y. Hong, X. Nie and C. M. Zepp, J. Org. Chem., 1994, 59, 1939-1942; J. F. Larrow and E. N. Jacobsen, Org. Synth., 1998, 75, 1-11; P. J. Walsh, D. K. Smith and C. Castello, J. Chem. Educ., 1998, 75, 1459-1462.

29 J. Balsells, L. Mejorado, M. Phillips, F. Ortega, G. Aguire, R. Somanathan and P. J. Walsh, Tetrahedron: Asymmetry, 1998, 9, 41354142.

30 B. K. Vriesema, J. Buter and R. M. Kellogg, J. Org. Chem., 1984, 49, 110-113; F. Chavez and A. D. Sherry, J. Org. Chem., 1989, 54, 29902992.

31 W. H. Kruizinga and R. M. Kellogg, J. Am. Chem. Soc., 1981, 103, 5183-5189.

32 J. J. Patel and C. L. Gibson, unpublished results.

33 A. G. Massey, Main Group Chemistry, Ellis Horwood, London, 1996, pp. 107-137; N. N. Greenwood and A. Earnshaw, Chemistry of the Elements, Pergamon Press, Oxford, 1984, pp. 69-106.

34 H. An, L. L. Cummins, R. H. Griffey, R. Bharadwaj, B. D. Haly, A. S. Fraser, L. Wilson-Lingardo, L. M. Risen, J. R. Wyatt and P. D. Cook, J. Am. Chem. Soc., 1997, 119, 3696-3708; N. Mohamed, U. Bhatt and G. Just, Tetrahedron Lett., 1998, 45, 8213-8216; U. Bhatt and G. Just, Helv. Chim. Acta, 2000, 83, 722-727.

35 W. Eschweiler, Ber. Dtsch. Chem. Ges., 1905, 38, 880-887; H. T. Clarke, H. B. Gillispie and S. Z. Weishaus, J. Am. Chem. Soc., 1933, 55, 45714587; S. H. Pine and B. L. Sanchez, J. Org. Chem., 1971, 36, 829-833.

36 K. Wieghardt, U. Bossek, D. Ventur and J. Weiss, J. Chem. Soc., Chem. Commun., 1995, 347-349.

$37 \mathrm{~K}$. Wieghardt and T. Weyhermüller, personal communication.

38 P. Wessig, F. Legart, B. Hoffmann and H.-G. Henning, LiebigsAnn. Chem., 1991, (10), 979-982.

39 E. J. Corey, R. I. Imwinkelried, S. Pikul and Y. B. Xiang, J. Am. Chem. Soc., 1989, 111, 5493-5495.

40 S. Hanesssian, M. Simard and S. Roelens, J. Am. Chem. Soc., 1995, 117, 7630-7645.

41 U. Gerlach, T. Haubenreich and S. Hunig, Chem. Ber., 1994, 127, 1969 1980.

42 S. Taylor, J. Gullick, P. McMorn, D. Bethell, P. C. Bulman Page, F. E. Hancock, F. King and G. J. Hutchings, J. Chem. Soc., Perkin Trans. 2, 2001, 1714-1723. 